\title{
Source, harvesting, conservation status, threats and management of indigenous plant used for respiratory infections and related symptoms in the Limpopo Province, South Africa
}

\author{
SEBUA SILAS SEMENYA ${ }^{1,2, \vartheta}$, ALFRED MAROYI ${ }^{2}$ \\ ${ }^{1}$ Technology Transfer Office, Research Administration and Development, University of Limpopo, Private Bag X1106, Sovenga 0727, South Africa. \\ Tel.: +27-152683938, ’email: sebuasemenya@gmail.com, sebua.semenya@ul.ac.za \\ ${ }^{2}$ Medicinal Plants and Economic Development (MPED) Research Centre, Department of Botany, University of Fort Hare, Private Bag X1314, Alice \\ 5700 , South Africa
}

Manuscript received: 26 August 2018. Revision accepted: 25 February 2019.

\begin{abstract}
Semenya SS, Maroyi A. 2019. Source, harvesting, conservation status, threats and management of indigenous plant used for respiratory infections and related symptoms in the Limpopo Province, South Africa. Biodiversitas 20: 790-811. This survey explored Bapedi traditional healer's (THs) practices pertinent to native plants used to treat respiratory infections (RIs) and related symptoms (RSs). Semi-structured questionnaires and participatory observations were used to gather information from 240 THs in the Limpopo Province, South Africa. 186 plants from 75 families were harvested by these THs, mainly from the communal lands (81.2\%), throughout the year. Plant parts used for RIs and RSs remedies was destructively harvested in wilderness compared to homegardens. Most ( $\mathrm{n}=174$ ) species from which these parts are obtained appears on the South African National Red Data List of plants, with $88.5 \%$ having a list concern status. This included Adansonia digitata, Boscia albitrunca, Catha edulis, Securidaca longepedunculata and Sclerocarya birrea which are also protected under the National Forest Act of 1998 (Act no. 84 of 1998). A further, 8.6\% ( $\mathrm{n}=15)$ of Red Data Listed plants are of conservation concern, with various status namely near threatened $(38.3 \%)$, declining $(20 \%)$, data deficient $(13.3 \%)$, critically endangered and vulnerable (3.3\%, for each), as well as endangered (6.6\%). There were both consensus and disjunction amongst THs and Red Data List regarding the status of plants in the wild. This study provides valuable data for the conservation of medicinal plants in Limpopo Province.
\end{abstract}

Keywords: Bapedi, Limpopo Province, traditional healers, respiratory infections

\section{INTRODUCTION}

Globally, the primary source of indigenous medicinal plant species implicated in the treatments of various human ailments including respiratory infections (RIs) and related symptoms (RSs) are mainly harvested in the communal land. However, the demands for such species by the majority of the people in developing countries especially in Africa have been met by destructive harvesting practices. This involves indiscriminate collection of species, unacceptable collection frequencies, harvesting of roots via uprooting entire species, and ring-barking of stem bark, amongst the others. All these improper practices are common in most African countries, to list few Uganda (Bukuluki et al. 2014), Mozambique (Bruschi et al. 2014), Nigeria (Ita and Offiong 2013) and Tanzania (Augustino and Gillah 2005). South Africa is also not spared from such unacceptable practices, and few studies (Dold and Cocks 2002; Geldenhuys and Williams 2005; Magoro 2008) highlighted this. However, the referred practices have not only been constantly reported in the above-listed African literature as threatening the survival of native medicinal plants resources, but also the people that depend on these resources for health care.

Evidence (Kipkemoi et al. 2013; Omogbadegun et al. 2011; Makueti et al. 2015; Rasethe 2017) exists highlighting that some of the indigenous plant species destructively harvested in most African countries including South Africa for the utilization as therapies for human illnesses encompassed those that are legally threatened or protected, and or both. Dejectedly, in African countries such as Zimbabwe (Mukamuri and Kozanayi 2001), Cameroon (Bellewang 2005), Kenya (Njoroge et al. 2010) and South Africa (Williams et al. 2013) a number of these species were authenticated as being either locally near extinct or extinct in the wilderness. Many of such taxa are also recognized by local harvesters such as traditional healers (THs), herbal medicine traders and lay people as difficult to obtain in the collection sites (Cunningham 1993). This will in the long run have a negative impact on the livelihoods of these harvesters, especially $\mathrm{THs}$, who may no longer be self-sufficient without them.

Generally, native plants also face a multitude of threats from other factors including habitat loss through various ways (such as clearances of land for agricultural practices and human settlements), the growth of the market economy, globalization, and acculturation (Ramakrishnappa 2002). Lack of both management and knowledge of conservation strategies are also threats to indigenous medicinal plant species. To avoid loss of these species, Law and Salick (2007), wrote that the basic research determining their sustainable conservation practices by users, conservation 
status, as well as threatening factors would greatly assist in both identifying priority species for conservation and setting suitable conservation programmes. In response to this, the present study aimed to comprehensively investigate the harvesting practices, conservation status, threats and management of indigenous plants implicated by THs in the treatments of RIs and RSs in the Limpopo Province of South Africa.

\section{MATERIALS AND METHODS}

\section{Location of study}

The study was carried out in the municipalities of Capricorn, Sekhukhune and Waterberg districts of Limpopo Province, South Africa (Figure 1). A total of five rural communities from each municipality were selected as study site. The selected villages are cultural homes to rural Pedi-speaking people who belong to Bapedi ethnic group. According to census report from Statistic South Africa (2011), Bapedi tribe are predominant in the Limpopo Province, constituting over $52.94 \%$ of the entire population.
The studied districts lie within various climatic zones. Capricorn lies on a subtropical climatic area, with most of the precipitation falling between October and March (Rautenbach et al. 2006). According to the report from Capricorn District Municipality (2013-2014), winter temperatures in this district rarely fall below $0^{\circ} \mathrm{C}$, with summer temperatures often exceeding $35^{\circ} \mathrm{C}$. Sekhukhune is characterized by a moderate climate with warm moist summer and cool dry winter (Victor et al. 2005). Average annual rainfall in Sekhukhune was $551 \mathrm{~mm}$, and the temperature ranged from a minimum of $7^{\circ} \mathrm{C}$ (in winter) to a maximum of $28^{\circ} \mathrm{C}$ (in summer) (Sekhukhune District Municipality 2008). Comparably to the Capricorn and Sekhukhune District, Waterberg is characterized by several climatic conditions. The northern and western regions experienced a hot and semi-arid climate, while the southern and eastern regions are more humid and slightly cooler (Waterberg District Municipality 2014-2015). Regions within the Waterberg district received high rainfall lasting from November to March, with intensity ranging from 600 $\mathrm{mm}$ to $650 \mathrm{~mm}$ yearly (Waterberg District Municipality 2014-2015).

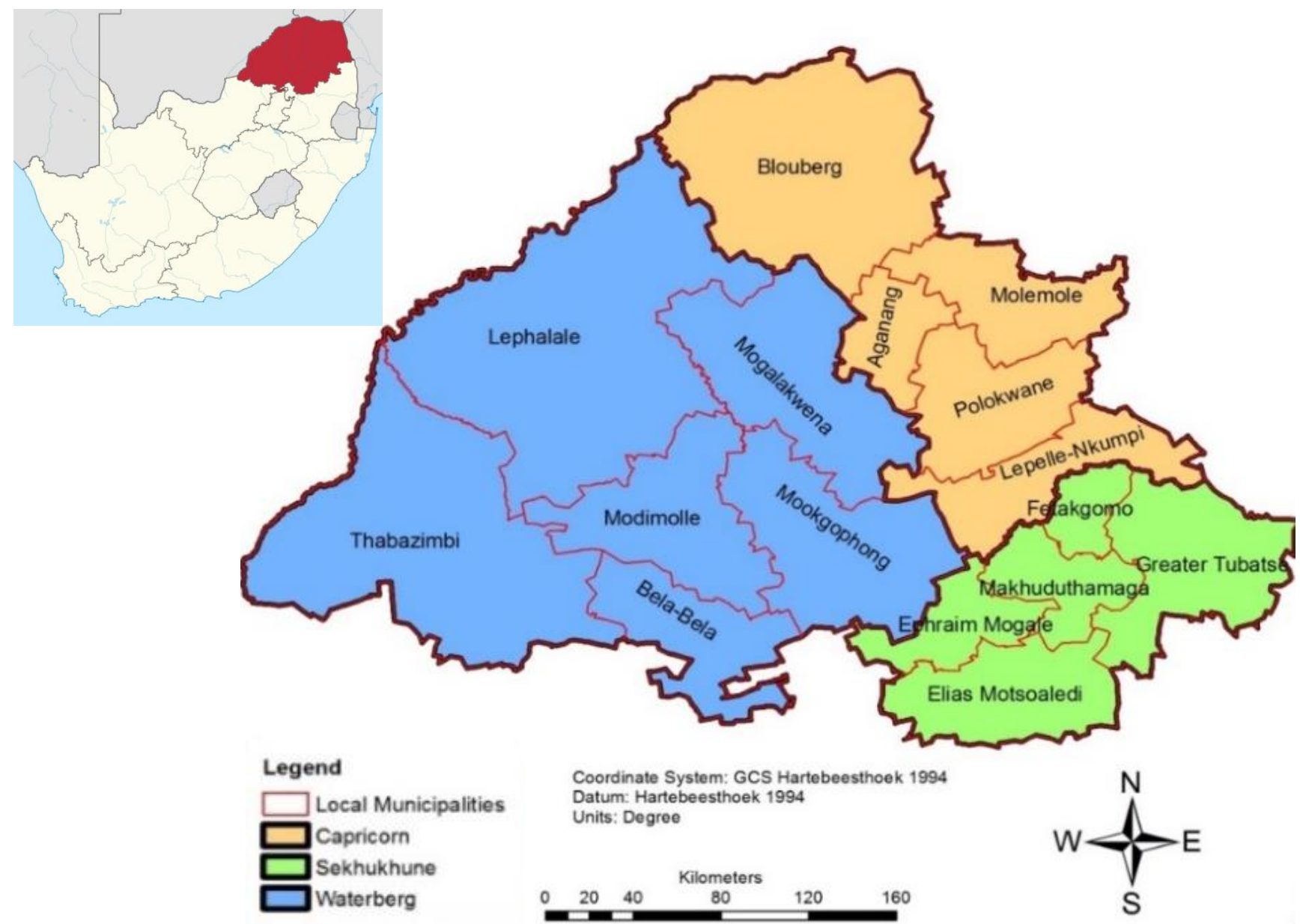

Figure 1. Map of the studied area (districts and municipalities) in Limpopo Province, South Africa 
The vegetation units within the Capricorn, Sekhukhune, and Waterberg districts were mainly identical and characterized by a mixture of herbs, trees and shrubs (Mucina and Rutherford 2006). However, vegetation types comparison within these districts show that Capricorn is mainly covered by Makhado Sweet bushveld (i.e., with Combretum apiculatum (Sond.) subsp. apiculatum, Hirpicium bechuanense (S. Moore) Roessler., Osteospermum muricatum E. Mey. Ex. DC. and Terminalia sericea Burch. ex DC., being amongst the most important taxa) and Polokwane Plateau Bushveld (i.e., mainly dominated by species such as Gymnosporia senegalensis (Lam.) Loes., Lippia javanica (Burm.f.) Spreng., Lantana rugosa Thunb. and Ziziphus mucronata Willd. subsp. mucronata, amongst the others). Floristically, Sekhukhune is characterized by Ohrigstad Mountain Busveld (i.e., with Acacia exuvialis I. Verd., Croton gratissimus Burch. var. gratissimus, Psiadia punctulata (DC.) Vatke. and Pterolobium stellatum (Forssk.) Brenan. being amongst the most presented species) and Sekhukhune Mountain Bushveld floral types (i.e., predominantly covered by numerous species including Barleria saxatilis Oberm., Clerodendrum ternatum Schinz, Commelina africana L. and Dichrostachys cinerea L. and kirkia wilsmsii Engl). Floristic elements across the Waterberg district comprises mostly of Central Sandy Bushveld (i.e., typically covered by Eragrotis nindensis Ficalho \& Hiern and Dichapetalum cymosum (Hook.) Engl., Ficus burkei (Miq.) Miq., Geigeria burkei Harv. subsp. burkei var. hirtella merxm and Hypoxis hemerocallidea Fisch., C.A.Mey. \& Avé-Lall) and Waterberg Mountain Bushveld (i.e., mainly characterized by species such as Acacia robusta Burch., Chamaecrista mimosoides (L.) Greene and Hibiscus meyeri Harv. subsp. meyeri).

\section{Ethnobotanical survey and data collection}

The actual ethnobotanical data gathering was preceded by a preliminary survey to request THs to participate in this study and also to seek permission from local traditional leaders to conduct the survey within the area of their jurisdiction. Data collection was done from May 2017 to October 2017 using a semi-structured face-to-face interview, complemented by field observation with 240 conveniently selected THs (i.e., with the help of local tribal leader and THs). This questionnaire were designed to collect data on the diversity of indigenous plants used for RIs and RSs, source of plants, used plant parts including harvesting frequencies and volumes collected, techniques used to harvest plant parts, THs' perception regarding the conservation status of each species and factors threatening them as well as management, knowledge of threatened species and legislative impacts. Interviews were conducted independently with each healer in their premises using the local Sepedi language, after obtaining a consent form.

An interview session was followed by field visit (i.e., in home gardens and communal lands) with each healer for personal observations. During the field excursions the THs pointed out medicinal plant species which they collect via Sepedi vernacular name/s, demonstrated the harvesting method/s, shared information on the availability status of each species (i.e., to communicate whether the species is declining in the wild, still reasonably abundant, near extinct and extinct in the wild) and factors threatening their survival. Overall the field observation was made in the morning (i.e., from $5 \mathrm{~h} 00$ to $11 \mathrm{~h} 00$ depending on an individual healer). This was reported by THs as a Pedi traditional practice erudite from ancestors and mentors. Specimens of all species identified by THs were collected, prepared and deposited at the Larry Leach Herbarium (University of Limpopo) for taxonomic identification by an expert.

\section{Data analysis \\ Micro Soft Excel and Statistical Package for the Social Sciences (SPSS)}

Microsoft Excel 2000 and SPSS version 14.0 were used to analyze data. Information collected through a semistructured questionnaire and field observations were tabulated into meaningful patterns and summarised using descriptive statistics such as frequencies and percentages.

\section{Conservation status: Red Data List}

The official conservation status of each species was analyzed and determined using the criteria outlined by the South African National Red Data List of plants (South African Biodiversity Institute 2017). For instance, the repertoire of species recorded in this study was compared to national red data list of plants (Table S1). Description of different conservation status criteria outlined by the South African Biodiversity Institute is provided in Table S1 as "note/legend."

\section{Conservation legislations}

National Forest Act (NFA) of 1998 (Act no. 84 of 1998) and National Environmental Management: Biodiversity Act of 2004 (NEMBA) was used to determine whether the species used Bapedi THs for RIs and RSs are protected or not. For instance, the list of taxa protected by these legislations were compared to those documented in this study.

\section{Free listing technique}

This method as described by Quinlan (2005) was used to acquire information on the factors threatening the sustainable use of each species implicated by THs in the treatment of RIs and RSs. All questioned THs were individually requested to list threatening factors to medicinal plants they used for these conditions. Accordingly, the factor/s stated by most healers was considered as the most threat.

\section{RESULTS AND DISCUSSION}

\section{The diversity of used indigenous species and their source/s}

One hundred and eighty-six $(n=186)$ native plant species belonging to 142 genera and 75 botanical families, 
mainly the Fabaceae (24 spp.) Asteraceae (14 spp.), Malvaceae (13 spp.), Celastraceae and Euphorbiaceae (7 spp., for each) were harvested by Bapedi THs as RIs and RSs medicines (Table S1). This finding is a reflection of the role played by South African flora as source of herbal medicine, and also shows that Bapedi THs are more knowledgeable about the application of the diversity of native flora as the cure for RIs and RSs. However, one species namely Helichrysum gymnocomum was excluded from the analysis as it was purchased by all THs who utilize it from muthi shops (shops trading medicinal plants materials). Similarly, mainly due to its phenological stages, Aloe spp. did not show all the diagnostic characters and could not be identified up to genus level; thus it was excluded from the assessment of its legal conservation status via South African National Red Data List of plants.

Overall, an overwhelming majority $(81.2 \%, n=151)$ of indigenous plants exploited by THs for the treatment of RIs and RSs were from communal lands, followed by homegardens $(27.9 \%, \mathrm{n}=52)$ and muthi shops $(4.3 \%, \mathrm{n}=8)$, respectively. The sum of these proportions adds to over 100 because some of the species were obtained by THs from more than one source. However, the reliant of THs on the free access wilderness to get most of the species calls for initiatives to encourage them to practice domestication.

\section{Harvesting of plants}

Plant collection and rituals

The current study revealed that an overwhelming majority $(91.6 \%)$ of THs collected their own medicinal plants. This practice came as no surprise as it was previously noted by Semenya (2012), amongst the Bapedi THs. As a matter of fact, such practice seems to be a general African pattern. For instance, Xhosa THs (Petersen 2014) of the Cape Town Province (South Africa), and VhaVenda THs (Rakuambo 2007) residing in the Limpopo Province (South Africa) also harvest the plant themselves. A similar finding was reported amongst the Shona THs practicing in the Guruve District of Zimbabwe (Kambizi and Afolayan 2006), and Massai THs from Samburu District, Kenya (Nanyingi et al. 2008). The latter THs exploited medicinal plants themselves to preserve the secrecy of the species locations (Nanyingi et al. 2008), while participants in our study collected to ensure that remedies prepared from acquired materials work effectively. According to Bapedi THs, for remedies to be effective, it must be collected by a person who has not had sexual intercourse for at least two days before collection. As such they collect their own plants to ensure sexual purity. In general, the practice of self-collection of healing plants adopted by most Bapedi THs might have an advantage from a conservation point of view as no middlemen are involved. This is because THs who are active harvesters of medicinal plants have incentives for plant conservations to ensure sustainability of their traditional healing practices (Tshisikhawe 2012). Also, many of such THs will try to harvest the required part/s carefully to guarantee the survival of the plant.

Nevertheless, a minority $(8.3 \%)$ of the interviewed Bapedi THs utilized trainees for the harvesting of curative plant species in the wilderness. This proportion mostly entails that of the THs who were too old and physically unfit to walk a long distance, climbing mountainous areas for materials collections. Prior medicinal plant collection, all interviewed Bapedi THs performed a specific ritual wherein a pounded leaf of an exotic species Nicotiana tabacum L. (Solanaceae) is dispersed around the species to be collected. According to THs, ritual is a means of expressing gratitude to the ancestors for revealing the plants, and to ensure that the medicine prepared from plants to be exploited work effectively. In addition, some THs stated that performing such rituals is part of a process of appeasing the ancestors before they grand them permission to plant exploitation. Chavunduka (1994) noted that the ancestors also play a role in transferring indigenous healing knowledge to African THs so that they are able to collect the correct species, process it correctly and safely treat patients. Therefore, involvement of ancestors by Bapedi THs prior medicinal plant species exploitation is an African cultural system.

\section{Harvesting frequencies and volumes collected}

The regularities of harvesting the medicinal plant species used to treat RIs and RSs were determined in this study. Consequently, plants were generally harvested throughout the year, and there were high consistencies with regards to the harvesting frequencies amongst THs across the studied districts and municipalities. For instance, $87.5 \%$ of THs collected plants twice a month, and the remaining THs harvested once a month $(6.25 \%)$, once a week $(3.75 \%)$ and thrice a month (2.5\%), respectively. Loundou (2008) found that most Xhosa THs in Western Cape Province, South Africa harvest plants throughout the year, with the majority of them renewing their materials every month $(52 \%)$ and week $(17 \%)$. Traditional healers in other African countries like Madagascar harvest plants two to three times a week (Adams 2013). These inconsistencies in the frequency of medicinal plants collection amid Bapedi THs and other cultures can be attributed to various factors which include amongst the others the curative plant availability in local bio-geographical regions. It is crucial to emphasize that all THs in this study disclosed that as per their traditions and beliefs, they formerly harvested the species only during summer and winter seasons. However, due to the continuing scarcity of plants in the collection sites and increasing distance to these sites both caused by the cash-needy harvesters (who gather larger quantities of materials every time of the year when out of stock), they changed these harvesting customs to the earlier alluded frequencies. This was to ensure that they also have species to sustain their traditional healing practices. The periods of harvesting healing plants by Bapedi THs generally depended on the availability of the targeted plant parts. Plant organs such as stem bark, twigs, and underground parts (bulbs, tubers, rhizomes, and roots) were collected throughout the year, perhaps because the species from which they are extracted are identifiable all year round. Seasonality (spring) only played a role when plant parts such as fruits, some leaves, seeds, and entire plants were to be collected, which might suggest that these parts are 
available in abundant during spring. Analysis of frequencies of the species collection by THs in their respective districts and municipalities mainly followed a uniform trend observed above. Overall, the harvesting frequencies adopted by in this survey might raise concern, as some plant species take very long to recover after parts have been removed. Cunningham (2001) stated that harvesting impact on a plant depends upon the frequency, that the more often the species is harvested the greater the impact.

The quantities of medicinal materials, especially of an individual species harvested by Bapedi THs as treatments for RIs and RSs, were difficult to determine, as the collection was not directed explicitly for plants used for these diseases, but other afflictions as well. According to THs, this practice of collecting multiple-therapies is motivated by the increased distances to their popular harvesting sites, and they further stated that it is both costeffective and sensible to gather various plants treating diverse categories of ailments when out for collection. Therefore, studies aimed at quantifying the therapeutic plant materials harvested in particular communal land should take this finding into consideration during the design phase. Overall, THs estimated the collection quantities of the plant used for RIs and RSs regarding the carrier bags, and other means of carriage. Most (85.8\%) of them across the studied district used $25 \mathrm{~kg}$ maize meal bags to physically convey single species per harvesting trip. Dold and Cocks (2002) reported almost a similar finding amongst the Xhosa in the Eastern Cape Province, although no $\mathrm{kg}$ was specified (but gave quantities of harvested medicinal plant materials regarding the container or carrier bag they use for transporting them to homes). With particular references to the present study, the frequencies of species collection, coupled with the quantity of materials extracted which can be appraised by the size of carriage bag $(25 \mathrm{~kg})$ used by most of Bapedi THs in their respective municipalities, has potential to hampers the regeneration of the species especially those that are slow growing and habitat-specific, which are either harvested for their undergrounds parts or entire plants. On the other hand, carriage of collected plant materials $(25 \mathrm{~kg})$ via own vehicles by some THs $(14.1 \%, \mathrm{n}=34)$ practicing in the Bela-Bela (46.6\%, $\mathrm{n}=7)$, Fetakgomo (20\%, $\mathrm{n}=3)$, Modimolle and Molemole (26.6\%, $\mathrm{n}=4$, for each), Mookgophong (53.3\%, $\mathrm{n}=8)$, Lephalale $(13 \%, \mathrm{n}=2)$ and Thabazimbi $(40 \%$, no $=6)$ municipalities might encourage over-exploitation and even local extinction of species due to the fact that no physical strength is used to transport the materials to their homes. We agree with Attwell and Cotterill (2000) who stated that the sustainable harvesting and use of medicinal plants would be difficult to achieve due to the modern-day context of technological advancement, particularly vehicles and harvesting machines.

For plant species which were obtained in communal lands of other districts, a vast majority $(91.6 \%, \mathrm{n}=220)$ of Bapedi THs irrespective of whether they own vehicles or not, revealed that they team-up with colleagues and hire a special transport, preferably a small truck. Although an overwhelming majority of THs stressed that they utilize 25 $\mathrm{kg}$ bag to carry individual species from collection sites, this is, however, not the case for taxa harvested from foreign communal lands. For instance, THs disclosed that they gather as many plants as possible to avoid both species shortage and a recurrent visit to these lands. This is a gluttony practice which could have a devastating effect on the environment and the local availability of species. About $8.2 \%$ of THs specifically those practicing in the Blouberg and Makhuduthamaga municipalities reported that they exchange 25 or $50 \mathrm{~kg}$ bags full of species with THs residing in other areas, in order to obtain scarce species or those that do not occur naturally in their communal lands. Overall, the regulation of the quantity of medicinal plants harvesting in the communal lands within the studied districts and municipalities can only be successful, if nature conservators team-up with the local indigenous groups particularly various users (plant sellers and healers) of these plants and traditional leaders who have over years managed and ensured sustainability of natural plant resources. As part of the partnership, local nature conservators should assist these indigenous groups to develop the management plans for collection sites, while encouraging a value system that promotes respect for the environment and sustainable utilization of natural resources.

\section{Techniques used to harvest plant parts}

Different morphological parts such as leaf, root, and seed from the native plants recorded in this study were collected using modern metal equipment such as axes, knives, and shovels, as well as hands. Naidoo and Nyakale (2000) observed that these advanced tools are more destructive because they harvest larger amount of materials within a short space of time compared to the ancient tools like pointed wooden sticks, and stone axes. Therefore, their utilization might be for maximization of harvest. Regulations of destructive harvesting tools as should as such be seen as one of the crucial starting points to tackle both over-exploitation and unsustainable harvesting techniques of curative plants in the wilderness while promoting the utilization of old equipment as substitutions. In general, use of the earlier alluded modern equipment by Bapedi THs depended on the type of pant habit and plant part/s to be harvested.

\section{Underground parts}

The subterranean parts of plants harvested by Bapedi THs made-up $78.3 \%$ (bulb $4.1 \%$; root $92.4 \%$; tuber $2.7 \%$, and rhizome $0.6 \%$ ) of all the organs extracted from the 185 indigenous species documented in this study, therefore being the most highly and widely exploited parts. This finding is comparable to that reported by various researchers in South Africa and other African countries. For instance, Monakisi (2007) who worked with Batswana THs of Kimberley, Northern Cape (South Africa) also found that the underground parts are mostly harvested. A similar finding was noted by Mahwasane et al. (2013) amongst VhaVenda THs in Limpopo Province (South Africa). In a study conducted in Ethiopia, underground 
parts accounted for 58.3\% (Abebe and Ayehu 1993). Extensive use of these parts of the plant in the present study calls urgent attention. This is because the parts are critical to the survival of any plant, playing a vital role of water and nutrients absorption (Monakisi 2007). Hence their damage might seriously endanger or even result in the death of the whole plant.

Amongst the various subterranean parts used in this study, roots were the utmost preferred, exploited from various habits namely tree $(n=71)$, herb $(n=32)$ and shrub $(n=31)$ compared to other subterranean parts which were exclusively obtained from herbaceous species. It can, therefore, be said that the extensive exploitation of roots by Bapedi THs have the potential to affect individual species including its floristic composition and structure. Overall, most of these THs (97.9\%) harvested the subterranean plant parts in the early hours of the morning. This was practiced mainly because it is an old custom learned from their ancestors and mentors. It is also probable that harvesting of such parts in the morning is much easier because soil conditions allow easy extraction due to the presence of dew, as opposed to midday which is normally characterized by a dry ground, thus very difficult to dig out. The remaining THs (2\%) collected healing plant materials any time of the day, which might be attributed to the sharp metal tools they use to dig the ground.

In general, the collection procedures employed by Bapedi THs for harvesting the underground parts of the plants were in most cases compatible across the three districts and their municipalities, which would let one believe that it is the Bapedi THs' standard protocol of obtaining these parts. An overwhelming majority of THs $(n=238)$ did not re-fill the soil after removing underground parts, claiming that such practice will worsen a patient's illness, an observation which were previously made by Magoro (2008) amongst the same THs. On the contrary, other researchers who worked with THs of various cultures in South Africa (Tshisikhawe 2002) reported refilling of soil after harvesting underground parts, stating that it is a taboo to not adhere to this practice. Nevertheless, the practice of not refilling the soil from which the underground part of the plant was removed as observed in our study might have negative impact on species survival. For instance, it has the potential to result in the following (i) plant water up-take reduction, (ii) plant carbohydrate reserve depletion and (iii) nutrient flow disruption or increase susceptibility to fungal attack (Botha et al. 2004), all which might singly or synergistically kill the species.

On the other hand, it was observed during field-work that all questioned Bapedi THs did not collect underground parts from taxa previously exploited by someone else, claiming that former harvester collected root which carried the healing power. THs easily identified previously extracted taxon by observing the marked effect of a pit. Such practice has great potential to reduce extensive harvesting of an individual plant species.

Analysis of the results obtained in the present study further showed that there was a clear harvesting pattern between the subterranean parts collected from the homegardens and communal lands. Harvesting of the bulbs
(Drimia elata, Drimia sanguinea, Eucomis autumnalis, Eucomis pallidiflora and Tulbaghia violacea) and tubers (Hypoxis hemerocallidea and Hypoxis obtusa) from the mentioned herbs retained in homegardens by THs involved their cutting with a knife from the base living roots in the ground. This practice is sustainable chiefly because the plates at the base of the bulb and tuber are important for regrowth of the plant (Alam 2013). Similarly, alternative practices of removing certain sections of underground medicinal plant materials from the above-listed species by some questioned THs (5.4\%) using a knife, but leaving other portions intact are also sustainable, as it does not result in plant fatality (Wilder and Edholm 2008). The same techniques were employed for the collection of herbaceous species such as Asparagus buchananii, Callilepis laureola, Cucumis metuliferus, Momordica balsamina, Pennisetum glaucum, Portulaca oleracea, Sansevieria hyacinthoides, Stachys aethiopica and Tylosema esculentum cultivated or retained in the homegardens for their medicinal roots. Therefore, it can be said that Bapedi THs are knowledgeable about the harvesting procedures that promote both sustainability and conservation of species. Regardless of this, their harvesting of the same parts (bulbs, tubers and roots) parallel to that of the above-mentioned species, also from comparable habits (herbs) although of various species procured from the free access wilderness areas was done in a very unsustainable and destructive manner, subsequently signifying that Bapedi THs only practice sustainable harvesting methods of medicinal plant which they have full control of. For instance, all THs who used tubers (Alepidea amatymbica, Dioscorea dregeana and Dioscorea sylvatica) and bulb (Siphonochilus aethiopicus) from the stated taxa occurring in the communal lands harvested them via pulling-out the entire plant using a shovel and other sharp objects. This practice results in the death of the entire plant since tap root is affected (Mander 1998). In KwaZulu-Natal Province, $S$. aethiopicus (Williams et al. 2001) and A. amatymbica (Cunningham 1993) is already locally extinct due to harvesting by uprooting. The latter species is also drastically declining in neighboring countries like Lesotho (Golding 2002), and Swaziland (Cunningham 1993). It will, therefore, not be a surprise if the population of some of the above-stated species particularly S. aethiopicus go locally extinct in the Limpopo Province, due to both unsustainable collection techniques and overexploitation. For instance, THs from as far as KwaZulu-Natal and Mpumalanga Provinces (South Africa) travel extremely long distances to Limpopo just to harvest this species (Coopoosamy and Naidoo 2012). Comparable to the exploitation of bulb and tuber obtained from herbs distributed in the communal lands, harvesting of roots from herbaceous species such as Adiantum capillus-veneris, Aptosimum lugardiae, Asparagus angusticladus, Clematis brachiata, Clivia caulescens, Commelina africana, Commelina subulata, Cyphostemma humile, Cyphostemma woodii, Dicoma anomala, Euphorbia schinzii, Jatropha zeyheri, Pergularia daemia, Rhoicissus tomentosa, Rhoicissus tridentate, Rhynchosia hirta, Senna italica, Solanum panduriforme, Stylochaeton natalensis, Tylosema 
fassoglense, Vernonia natalensis, Vigna frutescens, Waltheria indica and Zantedeshia aethiopica occurring in these lands was done via uprooting the entire plant. The practice of uprooting the whole herbs specifically $D$. anomala to obtain roots was also reported by Monakisi (2007) for Batswana THs. Although not the same taxa, Muthaura et al. (2007), and Kisangau et al. (2011) also made a similar observation amid the Digo THs in Kenya, and Kihaya THs of Tanzania, respectively. This destructive technique of harvesting roots via uprooting entire herbaceous species was reported by Bapedi THs as swift and less time consuming, thus makes the collection of roots much easier and ultimately maximize the harvest. Exceptional harvesting of roots from cultivated herbaceous species via uprooting was noted for Citrullus lanatus and $S$. aethiopica. According to the interviewed THs, these species are only available for a short period during rainy summer months. Interestingly, THs indicated that after digging-out the entire $S$. aethiopica, they air-dry them. Subsequently, shivers the dried materials on the specific portion tilled within the garden to disperse the seeds for regrowth in the favorable seasons. For $C$. lanatus, they emphasized that after obtaining its roots for medicinal usage, they preserve the seeds for the cultivation. All these further support the earlier alluded view that Bapedi THs only practice the sustainable harvesting methods of underground parts for medicinal plants they are in full control of.

Similarly, harvesting of roots from the following tree species; Adansonia digitata, Carissa bispinosa, Croton gratissimus, Commiphora marlothii, Dodonaea viscosa, Elaeodendron transvaalense, Encephalartos transvenosus, Gymnosporia senegalensis, Mimusops obovata, Peltophorum africanum, Salix mucronata, Vangueria infausta, Zanthoxylum capense and Ziziphus mucronata found in their homegardens involved the removal of few lateral roots. On contrary, exploitation of roots from both shrubs and trees in the communal lands by most Bapedi THs were generally done via the collection of larger quantities of the materials from a single species. The practice of removing these quantities of roots materials has been reported by Akerele et al. (1991), as the most harmful harvesting method for trees that present a threat to their existence. Such practice could therefore lead to extinction of big trees such as C. gratissimus, Dichrostachys cinerea, Mundulea sericea, Protea caffra, Sclerocarya birrea, Zanthoxylum capense, Zanthoxylum humile and Ziziphus mucronata that are slow-growing or take many years to reach maturity stage. Subsequently, this will force THs to targets juveniles for roots harvesting, therefore, causing an even greater impact on the local extinction of entire population. Over exploitation of root materials from $C$. gratissimus (Lepelle-Nkumpi) and $Z$. capense (all studied municipalities) by THs in the mentioned municipalities were mainly motivated by high species demand coupled with local scarceness. Healers, therefore, harvest a larger quantity of materials and store them for future usage. Bukuluki et al. (2014) reported similar finding amongst THs in Kampala and Mbale districts, Uganda. Unless conservation measures are taken to address the issue of over-harvesting and destructive collection techniques practiced by THs in the studied districts and municipalities, the survival of all the above-mentioned tree species will be endangered and ultimately go extinct. Likewise, conservation measures are urgently needed to both ensure long-term availability and safeguarding of wild harvested shrubby species such as Abutilon galpinii, Adenia fruticosa, Agapanthus inapertus, Blepharis diversispina, Blepharis subvolubilis, Buddleja salvifolia, Elephantorrhiza burkei, Elephantorrhiza goetzei, Flueggea virosa, Garcinia gerrardii, Grewia hispida, Gossypium herbaceum, Indigofera circinnata, Ipomoea albivenia, Lasiosiphon caffer, Leonotis leonurus, Maerua juncea, Plumbago zeylanica, Psiadia punctulata, Pyrenacantha grandiflora, Sida cordifolia, Strophanthus speciosus, Triaspis glaucophylla, Turraea obtusifolia, Vernonia wollastonii, $W$. somnifera and $Z$. zeyheriana from extinction or depletion. These species were entirely uprooted by Bapedi THs to obtain roots materials. Harvesting of E. burkei and M. juncea via uprooting was also reported by Mathibela (2013), amongst the Bapedi THs in the Blouberg municipality. The main reason for using this method in the present study was twofold: firstly, it was for ease harvesting of roots. For instance, THs generally dig-out the entire plants and gather them in one place particularly under tree shade, and thereafter focus on roots collection. Secondly, some of the above-listed species especially L. caffer, P. zeylanica, and S. speciosus were uprooted by THs to maximize roots harvest, because they are very difficult to find in the communal lands. According to THs if they can leave these species, local medicinal plant traders will come and remove them; thus it is better they uproot the entire plant and store material for future treatments of patients. Overall, this study clearly shows that Bapedi THs are erudite about the sustainable harvesting techniques of attaining underground parts from various plant habits. This was evident when collecting medicinal plants occurring in their homegardens. Therefore, their utilization of the destructive collection methods on wild distributed species is wholly a deliberate personal choice. Their constant reminder about both the advantage of the long-term availability of the species and the use of sustainable harvesting methods to their professional work perhaps can one day change their comportment.

\section{Bark}

Generally, the bark was harvested by THs with an axe or metal machete. Species they exploited for their bark constituted $4.3 \%$ and were exclusively trees namely Cassia abbreviata, Cryptocarya transvaalensis, Erythrina lysistemon, Kirkia wilmsii, Peltophorum africanum, Philenoptera violacea, Sclerocarya birrea and Warburgia salutaris. This is because it is a common practice for THs to collect bark from trees (Tshisikhawe 2002). Harvesting of the above-listed trees for their bark by Bapedi THs was done at any time of the day, probably due to both the ease of species identification and less labour. For instance, bark can be simply stripped off-using an axe or a metal machete while standing and no digging or washing is necessary. Methods used for collecting bark were mainly comparable 
amongst the THs in the studied districts and municipalities, irrespective of whether they are obtained from homegardens or free accessed communal lands. In fact, with the exclusion of $S$. birrea and W. salutaris, all species was consciously harvested for their bark by THs who utilize them without ring-barking the tree stem. For instance, trees stem was stripped only on the eastern side living other sides untouched. This method of harvesting stem bark is common amongst the THs of other South African cultures including VhaVenda (Mabogo 1990), and Zulu (Ndawonde 2006). A similar practice was also noted amid THs practicing in African countries such as Zimbabwe (Chapeyama 2009) and Uganda (Bukuluki et al. 2014). The technique of harvesting bark by some of THs including Bapedi seems to be primarily motivated by ethnic custom. For instance, VhaVenda utilized such technique to ensure the survival of the harvested tree, due to the belief that if it dies the prepared medicine will not be effective (Tshisikhawe 2002).

On the other hand, Bapedi THs belief that bark harvested using such methods are more effective. Nevertheless, field observation showed that utilization of such methods did not seem to hurt the tree, as previously collected species showed a good wound recovery. Struhsaker (1998) observed that sustainable harvesting activities involve the removal of a natural resource in a manner that does not deplete or compromise its ability to regenerate. It can, therefore, be noted that the techniques used by Bapedi THs for harvesting bark from some trees is sustainable, and should thus be promoted.

However, the above cannot be said with respect to the ring-baking techniques used by some of the THs for harvesting W. salutaris. Zschocke et al. (2000) witnessed that harvesting of bark from trees via this technique might kill the entire plants because it prevents transportation of nutrients throughout the plant and exposes it to diseases and insect attack. Indeed, our finding indicated that most of the individual species of $W$. salutaris harvested with such technique were dried-out and some even died. A similar observation was made by Kokwaro (1991) in Kenya. Individual species within the W. salutaris population which died due to ring-barking in the present study were mainly distributed on the mountainous areas around Mafefe village (Lepelle-Nkumpi). A higher number of this species with malformed trunks was chopped down to harvest the bark, and in some cases, the entire trees were felled to obtain this organ. During fieldwork it was observed that the targeted species was mainly those in immediate locations, probably because other plants are found on the topographic positions that are either difficult or too risky to access. A similar practice was also noted for $W$. salutaris population harvested around the Blouberg Mountains (Blouberg), although here none of the species were chopped down for bark collection, but instead, they were round stripped. Overall, the use of unsustainable harvesting methods for $W$. salutaris bark by some Bapedi THs might be attributed to their high demand by various collectors or users, and perhaps lack of knowledge about their stainable harvesting methods. These is ascribed to the fact that most THs who employ sustainable collection techniques of bark pointed- out some destructively exploited species during field-trips as the practice of either medicinal plant traders or THs who were not well traditionally trained about the bark collection. Therefore, promotion of sustainable bark harvesting methods should form should form the basis of any public awareness programme on medicinal species. Meanwhile, the utilization of W. salutaris leaves instead of bark would help in the prevention of the unsustainable use of bark material.

\section{Whole plant}

A total of $11(5.9 \%)$ native species comprising of herbs such as Adiantum capillus-veneris, Clerodendrum ternatum, Enicostema axillare, Euphorbia inaequilatera, Geigeria burkei, Helichrysum caespititium, Mentha longifolia, Monsonia angustifolia, Myrothamnus flabellifolius and Solanum catombelense, and a single shrub (Helichrysum kraussii) was harvested $(90.9 \%, \mathrm{n}=10)$ via uprooting (using shovels). Mathibela (2013) also stated the harvesting of M. flabellifolius by Bapedi through uprooting to obtain the whole plant. This practice is also rampant amongst THs in Uganda (Bukuluki et al. 2014). Harvesting of the entire plant by Bapedi THs was done in the morning when plants are still flourishing, to avoid their wilting (which makes it difficult for them to identify plants correctly) during the day. In general, harvesting of the entire plant in this study is because THs want to utilize all plant parts (underground parts, leaf, and flower) concurrently. According to THs it is much easier to remove the whole species instead of a couple of specific part/s required. This practice has enormous consequences on the targeted population and its diversity because it could lead to the rapid extinction of species since the entire plant is removed. Such destructive practice might affect the natural seed dispersal of species such as E. axillare, G. burkei and S. catombelense, which seemed to play a crucial part in their population reproduction, distribution, and expansion. To ensure the sustainability of both species population and ultimately medicinal plants availability, THs should be encouraged to harvest few parts or various selected parts from a single plant rather than uprooting the entire plant. Although this practice could be quite strenuous and timeconsuming especially when exploiting smaller herbs like $C$. ternatum, E. axillare, E. inaequilatera and $H$. caespititium, it will ensure sustainability of herbal remedies for the treatment of RIs and RSs as well as other ailments.

\section{Leaf}

Species harvested for their leaf made-up $10.8 \%$ in this study and were mainly shrubs (45\%), herbs (35\%) and trees (20\%), respectively. Methods utilized by THs for acquiring leaf from these habits were similar across the studied districts and mainly depended on the source of the plant. Leaf from shrubs such as Lippia javanica and Leonotis leonurus found in homegardens were acquired by handpicking without breaking the twigs. This technique of plucking leaves may not have detrimental adverse effects on medicinal plant materials availability, as the harvested taxa are not destroyed or mostly damaged (Khumalo et al. 2016). The opposite of this is true for leaves acquired from 
some shrubby (Athrixia phylicoides, Kalanchoe brachyloba, Lantana rugosa and Senecio serratuloides) species occurring in communal lands which was harvested by Bapedi THs via uprooting the entire species. Fortunately, their harvesting (irrespective of sources) of Aloe spp., Aloe falcata, and Aloe marlothii generally involved removal of few leaves with a knife far from to the base. During field-visits researcher observed that similar species previously exploited with this method were progressively recovering, which might be due to the fact that THs left some green leaves which allowed re-growth and the entire plants to photosynthesize. Regardless of this speculation, the Bapedi THs practices of harvesting Aloe species are sustainable. However, based on the earlier noted techniques they use for obtaining leaves from other species found in the communal lands, it can be speculated that their practices of harvesting Aloe leaves in the wild is due to both the limited competitions amongst harvesters, coupled with the year-round availability of leaves in abundant.

Comparably to some of the above-mentioned shrubby species, different harvesting techniques were also used by Bapedi THs for collecting leaves from herbaceous species found in the homegardens (Artemisia afra, Carpobrotus edulis and Cleome gynandra) and wilderness (Dicerocaryum senecioides, Tragia dioica, Vernonia natalensis and Waltheria indica). For instance, leaves of species from homegardens were collected via handpicking of the desired quantities while the harvesting of leaf of species occurring in the wilderness was thorough diggingout of the whole species with shovels, for later plucking at home. This technique was employed by THs because is time-saving and maximize the harvest.

Leaf from tree species such as Clerodendrum glabrum, Portulacaria afra, Terminalia sericea and Warburgia salutaris was acquired through hand-picking by cutting off the twig with shears. This practice was mentioned by Bapedi THs as having an advantage because it ensures both ease harvesting and assemblage of more significant amounts of materials in a short period of time. Generally, such practice could cause potential harm to the harvested taxa by decreasing plant's photosynthetic capacity. This might be particularly true for taxa such as W. salutaris, $T$. sericea and $P$. afra which are fairly slow-growing. These plants are vulnerable to overharvest and might not be able to withstand higher rates of leaves harvest, especially the evergreens like $W$. salutaris and $P$. afra which are exploited throughout the year.

\section{Stem and twig}

These plant parts made-up the smallest proportion in this study and were exclusively obtained from two succulent shrubby species namely Adenia spinosa (stem) and Kleinia longiflora (twig) respectively in the wild. Their collection was done at any time of the day, perhaps due to their evergreen physiognomies which allows easy identification. Adenia spinosa stem was chopped by all THs who utilize it in the eastern and western sites using an axe, probably due to their high demand, and simplicity of harvesting this part. For instance, the stem or trunk of $A$. spinosa is always juicy and soft through the year, therefore allows easy removal. During field-trips researchers observed that previously harvested A. spinosa stem showed a good sign of recovery, suggesting that the impact of its harvesting does not affect the inner layer of the stem/trunk transporting and storing photosynthates. However, $A$. spinosa duration of recovery post harvesting remains unknown, and warrant further investigation to determine the suitability of harvesting frequencies and seasons.

Kleinia longiflora twig was harvested by hand via breaking of the required amounts by all THs who utilize it. Field observations indicated that previous species harvested with this technique responds well, which might be because its multiple twigs/branches are not uprooted or entirely harvested by Bapedi THs. Therefore, it can be said that the harvesting method $K$. longiflora twig by these THs does not have detrimental effects on its long-term health.

\section{Fruit and seed}

Fruit $(2.1 \%)$ and seed $(0.5 \%)$ was also harvested by Bapedi THs from a limited number of species which were exclusively trees (Ficus burkei and Sclerocarya birrea) and herbs (Citrullus lanatus and Cucumis zeyheri). Collection methods they used for obtaining fruit from the trees included hand-picking, throwing of stones at the tree to detouch them, knocking them down with long sticks and collect them from the grounds, and lastly breaking off branches to obtain them. These are common methods of collecting fruits from trees by indigenous people of South Africa (Rampedi, 2010) and other African countries such as Uganda (Okia et al. 2011) and Zimbabwe (Kadzere et al. 2004). The utilization of the previous techniques by Bapedi THs for obtaining fruits from $S$. birrea and F. burkei was actually expected due to the constraints related to the structural aspects of these trees as well as targeted fruits. For instance, most of the fruits might be too high for THs to reach them by hand. In this case, THs are forced to throw off stones at tree to de-touch fruits, or knock them down with long sticks and collect from the grounds. Also the harvesting of relatively smaller fruits from $F$. burkei might be labor-intensive, and time-consuming which THs do not have, thus healers' cut-off the branches bearing fruits and seat under a tree and harvest. Overall field-observation showed that former species harvested for their fruits via this method responds well. However, extensive utilization of such method on a single species might negatively affect their survival. None of THs hand-picked $S$. birrea and $F$. burkei fruits from the grounds after abscission, claiming that such fruits they are not fresh. This practice, therefore, has a positive conservation implication because it increases seedling establishment and natural seed-dispersal as more fruits carrying seeds are left on the ground.

Fruits from herbaceous species namely $C$. lanatus and C. zeyheri were easily hand-picked by THs, obviously due the fact that both these taxa are ground-spreading and thus are within the THs reach. Similarly, seeds were wholly collected via hand-picking from herbaceous species $(S$. bicolor). All these species are seasonal, and THs indicated that they leave some fruits with seeds to allow natural re- 
growth during favorable season. Besides, THs also preserve some seeds for cultivation.

\section{Conservation status of species via Red Data List of plants}

An overwhelming majority $(n=174)$ of plant species used by Bapedi THs as RIs and RSs therapies appears on the South African National Red Data List of plants (SANBI 2017). Amongst this species, $88.5 \%$ are categorized under a list concern status. This finding has a positive conservation implication mainly because more widespread and abundant species in the wild are included in this category. In other words, most of the medicinal plant species implicated by Bapedi THs in the treatment of RIs and RSs are at not threatened.

However, $3.2 \% \quad(\mathrm{n}=5)$ of species such as Adansonia digitata, Boscia albitrunca, Catha edulis, Securidaca longepedunculata and Sclerocarya birrea which also have a list concern status is protected under the National Forest Act (NFA) of 1998 (Act no. 84 of 1998), thus their exploitation without a permit from the relevant authorities is highly prohibited. Harvesting of these species seems to be a common practice in Limpopo Province. For instance, VhaVenda THs also harvest them for medicinal usage (Mabogo 1990). Boscia albitrunca, C. edulis, and S. longepedunculata were also featured amongst the most widely harvested and traded plants in Limpopo (Moeng 2010). Their widespread harvesting is therefore of concern mainly due to the fact that their populations are mostly naturally distributed in Limpopo Province across South Africa (SANBI 2017), and as such their extensive exploitations coupled with destructive harvesting techniques as observed in this study particularly for $C$. edulis, $S$. longepedunculata and $S$. birrea might in the long run have profound impact on both their local and national conservation status. This is especially true since their harvesting by local medicinal plant traders and THs continues with or without a collection permit, because of their high demand for remedy usage (Moeng 2010). Indeed, enforcement of conservation legislation prohibiting the collection and sale of protected species has done little to remedy the situation (Mander 1998). Meanwhile, we concur with Marshall (1998) who stated that educating resources-users regarding protected species while encouraging them to employ sustainable harvesting techniques will assist them in developing the management guidelines for the species collection.

Not surprisingly, $8.6 \%$ of Red Data listed plants used by the interviewed Bapedi THs are of conservation concern. This was anticipated mainly due to the fact that previous researchers (Magoro 2009; Mathibela 2013) who worked with same THs reported a similar finding. Medicinal use of threatened plant species is common amongst the THs of other South Africa cultures including VhaVenda (Tshisikhawe 2002), Zulu (Coopoosamy and Naidoo 2012) and Xhosa (Nzue 2009). This widespread use of threatened species across South Africa indicates that their population is under severe pressure of overexploitation. Amongst the species of conservation concern used by questioned Bapedi THs, 33.3\% encompassing
Adenia fruticosa, Clivia caulescens, Drimia sanguinea, Elaeodendron transvaalense and Eucomis pallidiflora are near threatened. These are species which are likely to become endangered in the wild within the foreseeable future (SANBI 2017). Fortunately, some of them particularly $D$. sanguinea, E. transvaalense and $E$. pallidiflora were harvested by Bapedi THs in the homegardens. The practice of domesticating or maintaining the threatened species in cultivated areas is in itself a conservation measure, mainly because it has the potential to reduce harvesting pressure of same species but distributed in the wild. Equally, such practice might be a destructive effort if THs conserve the species but at the same time continue to harvest them in the wild. However, harvesting of $A$. fruticosa and $C$. caulescens (roots) via uprooting by Bapedi THs calls for an urgent conservation measure to both safeguard them and avoid their listing on Red Data as endangered. This is exigent particularly for $C$. caulescens which seems to be affected by massive harvest pressures from both commercial trade and for local health care purposes across various areas of Limpopo. For instance, the previous study conducted in this province showed that THs (Mathibela 2013) and medicinal plant sellers (Moeng 2010) also harvest C. caulescens via pulling-out the entire species.

A further $20 \%$ of species namely Cryptocarya transvaalensis (bark), Eucomis autumnalis (bulb) and Hypoxis hemerocallidea (tuber) harvested for the stated parts by the interviewed THs in this study, which are described as of conservation concern are declining. Drimia elata and Myrothamnus flabellifolius which also appear as of conservation concern on the Red Data List of South African plants has data deficient status. These taxa are suspected to be threatened but insufficient information is available to place them in a category of threat (SANBI 2017). Findings from the present study suggest that $D$. elata and $M$. flabellifolius is extensively threatened by overharvesting, which has the potential to reduce their local population drastically. For instance, D. elata is now collected by Bapedi THs from homegardens, and on the other hand they harvest M. flabellifolius in the wild using a very destructive manner (e.g., via uprooting entire plant). Wild population of both species has already been reported by Moeng (2010) to be indiscriminately and destructively harvested by muthi traders across Limpopo Province. Thus detailed field work aimed at assessing their population is critically needed, as it will contribute to providing information that is much needed to decide their status on Red Data List.

The remaining plant species making-up $8.6 \%$ of taxa of conservation concern falls under the following categories; critically endangered (Brackenridgea zanguebarica and Siphonochilus aethiopicus), and vulnerable (Alepidea amatymbica and Dioscorea sylvatica), and endangered (Warburgia salutaris). These are species that are facing a high risk of extinction and are either close to be regionally extinct, extinct in the wild or completely extinct (SANBI 2017), thus are of extremely high conservation concern. Overall, their exploitation from natural habitats as observed in the present study has the potential to trigger their rapid 
regional extinction, especially with high demand and low population yield. This might be the case with $A$. amatymbica, D. sylvatica and $S$. aethiopicus which were both widely and destructively harvested (via-uproot entire plant) in the natural habitats by higher number interviewed THs in the present study. As noted earlier A. amatymbica and $S$. aethiopicus, as well as W. salutaris is now locally extinct in KwaZulu-Natal Province, South Africa due to both high demand coupled with destructive harvesting techniques. A similar finding was noted by Manzini (2005) but regarding $S$. aethiopicus in Mpumalanga Province, South Africa. Of serious concern are those THs from the above-stated provinces who now travel to Limpopo to harvest A. amatymbica, S. aethiopicus and W. salutaris. This has negative conservation repercussions as it increases harvesting pressure, which might result in the rapid local extinction of species. Overall to prevent the extinction of $A$. amatymbica, D. sylvatica, S. aethiopicus and W. salutaris, declaration of the habitats where population occurs as lawfully protected and simultaneously safeguarding them by establishing fence, will be a useful conservation tool for ensuring their continual survival. This will open doors for other conservation initiatives including but not limited to the augmentation of the population via cultivation of seedling.

Most importantly, development of medicinal plant nurseries of the above four mentioned taxa for all harvesters including THs and medicinal plant traders operating in the Limpopo is needed to increase the feasibility of sustainable harvest in cultivation and their preservation in the in situ area. This is especially vital since legislations aimed at managing medicinal plants seem to be not contributing positively towards their conservation. However, in situ conservation of B. zanguebarica with a controlled access for bark harvesting appears to be effective and significant strategy that ensures its continual survival in the natural environment (Tshisikhawe 2002).

The conservation status of the remaining species namely Euphorbia inaequilatera, Geigeria burkei, Plumbago zeylanica, Senna occidentalis and Xerophyta retinervis appearing on Red Data List is not formally evaluated. However, the high utilization (Table S1) of some of these species coupled with destructive harvesting techniques and frequencies of exploitation by Bapedi THs is an indication that they are overharvested, and might be drastically declining in the natural environment. It is therefore very imperative that the local population of such species be constantly monitored in order to determine their status and accordingly develop the management guidelines. This will not only avoid the listing of taxa as of conservation concern on Red Data List but will also ensure their continued availability for remedy preparations.

The above is also true for Acacia erioloba, Abutilon galpinii, Acacia senegal, Acacia sieberiana, Acacia tortilis, Clerodendrum glabrum, Combretum hereroense, Markhamia zanzibarica, Solanum panduriforme and Vernonia natalensis which are not included on the South African National Red Data List of plants. This is particularly true for widely exploited species such as $A$. erioloba and $V$. natalensis. Their high harvesting, along with the reality that they have multiple uses beyond RIs and RSs treatments, will subjects them to overexploitation, and consequently to scarcity. For instance, A. erioloba stem and twig is also extensively harvested for firewood while $V$. natalensis is a well-known multi-used medicinal plant treating a wide range of other prominent diseases (Plantzafrica 2016). Indeed, these taxa should meanwhile, continuously be monitored and managed, to ensure their sustainable harvest and prevent their local extinction while awaiting conservation status assessment and appearance on South African National Red Data List of plants.

\section{Red Data List vs. healers' perception on availability status of plants}

Amongst the 185 native species recorded, majority $(89.1 \%)$ were noted by Bapedi THs as still reasonably abundant in the communal lands. These species included amongst the others, legally protected Acacia erioloba, Adansonia digitata, Boscia albitrunca, Catha edulis, Sclerocarya birrea (National Forest Act of 1998 (Act no. 84 of 1998) and threatened Red Data Listed Brackenridgea zanguebarica as well as Cryptocarya transvaalensis. As depicted in Table S1, most of these species appear as least concern on the South African National Red Data List of plants, because they are still fairly abundant. This shows that information obtained from THs is reliable and they should, therefore, be key partners for effective local conservation and management of medicinal plant species.

Twenty-one percent of the native species documented in this study was perceived by THs as of conservation concern with different status. These encompasses Aloe spp. (88.3\%), Artemisia afra (33.7\%), Callilepis laureola (90.4\%), Clerodendrum ternatum (100\%), Drimia sanguinea (1.6\%), Enicostema axillare (100\%), Hypoxis hemerocallidea (9.1\%), Hypoxis obtusa (1.2\%), Myrothamnus flabellifolius (39.1\%), Osyris lanceolata (7.5\%), Securidaca longepedunculata (96.6\%) and Warburgia salutaris $(95.8 \%)$ which was noted by all THs who obtain them from communal lands as declining. High consensus amongst the Bapedi THs regarding the availability of these taxa might be an accurate reflection of the current local trend and status of their population. This is because the natural resource user's familiarity with their local natural environment makes them aware of the status of the resource long before conservationists detect it (Shanley and Luz 2003). Indeed H. hemerocallidea has a declining status on the Red Data List. Contrary to the finding of the current study, Magoro (2008) who questioned THs Bapedi regarding the availability status of this species reported it as in danger of extinction. This anomaly might be attributed to the variations with respect to the specific areas within the communal lands where THs harvest plants. Further analysis of findings in the present study showed that $D$. sanguinea, $H$. obtusa, $M$. flabellifolius and W. salutaris which were reported by Bapedi THs as declining appears as near threatened, least concern, data deficient and endangered respectively on Red Data List. Mander (1998) found that VhaTsonga people in Mpumalanga Province declared W. salutaris as declining. Similar findings were reported in various areas of Southern 
Africa (Maroyi 2013), which is not surprising, mainly because $W$. salutaris is part of the pharmacopoeia of traditional medical systems of many countries in this part of Africa wherein it is also commercially important. Consequently, its harvest is often indiscriminate, destructive, and unsustainable. Paradoxically to our results, Mathibela (2013) previously interviewed Bapedi THs in Limpopo Province reported that they recognize $M$. flabellifolius and W. salutaris as common and abundant. Our findings could therefore, be a reflection of the current or latest local availability status of these taxa in Limpopo.

The present study results showed $28.9 \%$ of taxa namely Alepidea amatymbica and Dioscorea sylvatica (vulnerable), Eucomis autumnalis (declining) and Siphonochilus aethiopicus (critically endangered) with the mentioned status on Red Data List was perceived by all THs who harvest them as near extinct in the communal lands. The perceived availability status (near extinct) of $A$. amatymbica and S. aethiopicus by Bapedi THs as recorded in the present study is contrary to rare status reported by muthi traders in 2010 across the different areas of Limpopo Province (Moeng 2010). This discrepancy might be a local indication of the extent to which plant species changed status over the years attributed to both overharvesting and unsustainable collection techniques. Some of the abovementioned species were also perceived by THs of other South African cultures as declining in the wild. For instance, Xhosa THs practicing in the Eastern Cape Province also reported A. amatymbica (Cocks and Dold 2002) and E. autumnalis (Koduru et al. 2007) as scarce in the communal lands. Overall, perceived status (i.e. near extinct) of all the above-mentioned taxa by Bapedi THs should not be dismissed, but viewed as an appeal for an immediate assessment of their population across Limpopo Province. Warburton and Martin (1999) found that the native people are the only ones known to provide useful and specific information regarding the recent status of their local plant resources; mainly because standard scientific methods alone may not adequately justify this assessment especially where direct harvesting for livelihoods use is evident.

Further analysis of finding from our survey revealed the geographical discrepancies amongst THs with respect to the availability status of some taxa. For instance, Garcinia gerrardii, Croton gratissimus, Elephantorrhiza goetzei, Gossypium herbaceum, Kalanchoe brachyloba, Protea. craffra, Senna italica, Vernonia natalensis, and Zanthoxylum capense which appears as least concern on Red Data List were reported by THs as declining and fairly abundant in their respective municipalities. However, the latter status was stated by vast majority of THs, which might be the actual current local status of the abovementioned species in the surveyed areas. The same is true for Stylochaeton natalensis. This species was also enumerated as least concern on Red Data List, and yet perceived by a higher number of interviewed Bapedi THs (96.2\%) as declining in their areas, with just $3.7 \%$ who noted it as still reasonably abundant. Overall, the geographical disparities with regards to the perceived status of the aforesaid taxa amongst the THs might be attributed to the local availability of species within their preferred specific collection areas. Regardless of this variations, we share similar sentiments with Victor and Keith (2004) who stated that Red Data Listed taxa with least concern status does not automatically mean that they are not worthy of conservation measures. The present study, in fact, showed that these taxa may be in need of conservation actions at the local levels.

Similarly, Dicoma anomala and Elephantorrhiza burkei both appearing as least concern on Red Data List were perceived by THs as being declining, fairly abundant and near extinct in their areas of collection. The discrepancies with respect to the perceived availability status of these medicinal plants amidst THs accentuate the significant of conducting population assessments at various harvesting sites for conservation measures. This is particularly urgent for the following taxa Drimia elata (data deficient), Eucomis pallidiflora (near threatened), Lasiosiphon caffer and Plumbago zeylanica (least concern) with the mentioned status on Red Data List. For instance, depending on THs, these species were perceived as declining and near extinct in the communal lands. Solanum catombelense was the only species reported by THs as still fairly abundant $(93.7 \%, \mathrm{n}=225)$ and near extinct $(6.2 \%, \mathrm{n}=15)$ in this study. Traditional healers who reported the latter status was exclusively from Modimolle Municipality (Waterberg district), thus suggesting that $S$. catombelense occurring in this area is under various severe threats including over collection and might face local extinction. In general, it is important that all THs perceptions regarding the availability status of the indigenous medicinal plants recorded in the current survey be taken into account by local conservationists and subsequently authenticates their views. This is because THs' views have the great potential to contribute to both a better understanding of conservation status of the plants and improvement of the Red Data List. As noted earlier standard scientific methods alone may not adequately justify the assessment of plant especially where direct harvesting for livelihoods use is evident.

\section{Factors threatening medicinal plants}

The current study has established that all wild-harvested native plant species implicated by Bapedi THs in the treatment of RIs and RSs across the three studied districts and municipalities were threatened by various factors namely overexploitation, unsustainable harvesting techniques, deforestation, fires (accidental or deliberate), limited rainfall, and overgrazing, respectively. These factors were not threats to all medicinal plant species:

\section{Unsustainable harvesting techniques}

This activity was reported by all questioned THs as the main threat to wild harvested species documented in this study. They pointed out highly and widely used species including Alepidea amatymbica, Dioscorea sylvatica and Siphonochilus aethiopicus as near extinct in the collection site due to unsustainable harvesting methods. This finding is in partial agreement to that noted by Dold and Cocks (2002) in the Eastern Cape. They found that both $A$. amatymbica and $D$. sylvatica are very scarce as the result 
of destructive harvesting techniques (i.e., via uprooting entire plant). Not surprising, all Bapedi THs queried in Blouberg (Capricorn district), and Mogalakwena (Waterberg district) mentioned S. aethiopicus as locally extinct due to these collection methods. Moeng (2010) who previously conducted surveys in these districts found that the local availability of $S$. aethiopicus has decreased to an alarming rate, mainly due to high demand for multiple medicinal applications and destructive collection techniques. As highlighted earlier, this species is already extinct in KwaZulu-Natal (Coopoosamy and Naidoo 2012) and Mpumalanga (Manzini 2005), with most harvesters from these provinces resorting to Limpopo for collection. Therefore, if the current uncontrolled collection of medicinal plants in Limpopo is not regulated, many species especially A. amatymbica, D. sylvatica and S. aethiopicus which have already been legally certified as threatened, will soon irreversibly disappear from the wild. Other species reported by Bapedi THs as being threatened because of unsustainable collection methods included Plumbago zeylanica and Lasiosiphon caffer. According to THs these species are either near extinct or declining in their respective areas. In general, the problem of employing unsustainable harvesting techniques on wild medicinal plants will be difficult to solve in the studied areas. This is because THs disclosed that they also intentionally utilize these techniques and are also aware of their consequence on the existence of harvested taxa. They reasoned that other active harvesters such as local muthi traders and unknown foreign collectors employ such methods to maximize harvest. Thus they do likewise to ensure the continuous availability of medicine for their traditional healing practice.

\section{Overexploitation}

Generally, overharvesting of medicinal plant species is one of the key issues of plant resource sustainability (Bodeker et al. 2014). In the present study, this activity was noted by all interviewed THs as a threat to recorded wild harvested plants. Artemisia afra (33.7\%), Enicostema axillare (100\%) and Warburgia salutaris (95.8\%) are examples of taxa mentioned by all THs who harvest them in the communal lands as declining due to overexploitation. A similar finding was noted by Mathibela (2013) for $A$. afra distributed on the Blouberg Mountain. Overall, the practice of over-collecting wild medicinal plants were reported by Bapedi THs as driven by the high demand of medicinal materials for use as multiple remedies. For instance, they revealed that all the above-three mentioned taxa are used for broad range ailments (i.e., stroke, HIV and malaria) apart from RIs and RSs. It is unfortunate that most of the overexploited species for usage as diverse medicines are slow-growing woody species (Geldenhuys and Williams 2005) and geophytes (Street and Prinsloo 2013). Indeed, the availability of woody taxa such as Elephantorrhiza burkei, Elephantorrhiza goetzei, and Zanthoxylum capense was recognized by a vast majority of THs in the current study as impacted due to overharvesting for multiple remedies applications. Likewise, the following geophytes; Drimia elata, Eucomis autumnalis, Eucomis pallidiflora, Drimia sanguinea, Hypoxis hemerocallidea and Hypoxis obtusa were acknowledged by most THs as very scarce in the communal lands. The scarcity of $D$. elata and $H$. hemerocallidea (Dold and Cocks 2002) as well as E. autumnalis (Koduru et al. 2007) due over-exploitation was also reported by the mentioned authors as common in the Eastern Cape. These findings thus, support the perception of Bapedi THs that medicinal species are threatened by overexploitation, and indicate that this activity is also a challenge in other areas of South Africa. Generally, the scarcity and decline in availability of taxa reported in the present study due to overexploitation buttress findings of Semenya (2012), who observed that multi-utilisation of curative plants have potential to exert intense pressure on some taxa, causing their overexploitation and ultimately local extinction. Therefore, conservation priority should also be given to taxa with multiple uses.

\section{Deforestation}

Deforestation was reported as threatening factor to medicinal plants by $52.5 \%$ of THs in this study. Chakravarty et al. (2011) defined deforestation as the cutting down of trees or clearance of natural vegetation for a variety of purposes including agriculture and human settlements. Species affected by these activities accounted for $4.3 \%$ in our study and included Croton gratissimus, Garcinia garcini, Dicoma anomala, Drimia elata, Eucomis pallidiflora, Kalanchoe brachyloba, Solanum catombelense and Vernonia natalensis. Impact of deforestation on these species were reported by THs in the selected municipalities of Capricorn and Waterberg, which might be an indication that more developmental activities take place in these districts. Availability status of D. elata, E. pallidiflora and S. catombelense (Modimolle), C. gratissimus (Aganang, Blouberg and Lepelle-Nkumpi), C. garcini (LepelleNkumpi) and D. anomala (Lepelle-Nkumpi, Lephalale, Modimolle and Mookgophong) were reported by THs from the mentioned municipalities as negatively affected due to clearance of natural vegetation for human settlements. These taxa will be lost to deforestation unless urgent measures are taken. Studies (Cunningham 2001; Hamilton et al. 2006) have shown that the expansion of human settlement is progressively replacing natural vegetation where most medicinal plants are found. In the context of our study, environmental impact assessment guiding land use and development in the rural areas should take in to account the distribution and local value of medicinal plants.

Availability status of the remaining plants namely $V$. natalensis (Modimolle and Mookgophong), K. brachyloba (Mookgophong) and S. italica (Bela-Bela) in the stated municipalities of Waterberg district were reported by THs as declining because of the clearance of natural vegetation for agricultural purposes. Agricultural development is also a significant threat to traditional medicine in other areas of South Africa (Thring and Weitz 2006) and Africa (Lulekal et al. 2008). The impact of this development in the abovementioned municipalities might be due to the fact the communal lands are mainly delimited by huge private farms, and protected areas, which increase competition of 
land acquisition amongst the residents for agricultural practices. It is recognized that in future, these competitions will escalate as population expand and ultimately result in even more land cleared for agriculture. This is highly probable partly due to the fact that agriculture is one of the important economic mainstays of people in the aforesaid municipalities. Therefore, to ensure the sustainability of traditional medical practices, THs in these municipalities need to grow medicinal plants in homegardens and legally obtain access to protected areas for sustainable medicinal plant collection.

\section{Fire, inadequate rainfalls and overgrazing}

Impact of these factors on therapeutic plant availability in this study was generally limited. For instance, of all the indigenous species $(\mathrm{n}=185)$ documented, only Callilepis laureola and Gossypium herbaceum were reported by few THs (16.2\%) questioned in the Sekhukhune district as declining due to fire. This finding might be an indication that both these herbaceous taxa cannot survive under fire. However, a detailed study focusing on the impact of fire on C. laureola and $G$. herbaceum will be a crucial starting point for their effective management. Meanwhile, the initiatives to locally prevent and control fire in the affected communal areas within the Sekhukhune through relevant information dissemination and appropriate fire control strategies are recommended.

Limited precipitation and overgrazing were exclusively reported by THs from Mookgophong municipality (Waterberg District) as impacting on the availability of $C$. laureola in the free access wilderness. According to these THs there has been a drastic decline of availability of this species in the harvesting areas, which they suspect is due to both these factors. Indeed, the impact of intensive overgrazing could lead to more habitat destruction and shrinkage of the natural population sizes of the valued medicinal plants (Wangchuk and Olsen 2010-2011). Effect of rainfall on wild plant population cannot be overemphasised. This is because most of these population if not all depend entirely on rainfall as part of their survival. Unfortunately, the availability of precipitation as a perceived threat to $C$. laureola by some THs in this study is not practical to manage, because it is beyond the control of human beings. Healers should, therefore, domesticate this species in homegardens. At least overgrazing can be managed via monitoring and determination of the appropriate rotation time for grazing live stocks to avoid its impact on the availability of medicinal plants for RIS and RSs.

\section{Plant conservation: Management, knowledge of threatened species and legislative impacts}

The present study has further established that traditional leaders in all studied areas excluding few in Modimolle (33.3\%, $\mathrm{n}=5)$ and Mookgophong (100\%, $\mathrm{n}=15)$ municipalities are responsible for the management of plant resources in their communal lands/wilderness. No one is accountable for the management of plant in these municipalities. Overall, the management approaches used by traditional leaders are general and not specific to a particular plant species. Amongst all the plant management strategies implemented by traditional leaders, the collection of larger quantity of plant materials, utilization of harvesting methods that might results in the plant fatality and harvesting of plants by foreigners without a permit from tribal office was stated by all THs as relevant to medicinal plant resources.

Similarly, they also stated a fines of R200.00 to R3000.00 (depending on THs location/s) is set by traditional leaders for harvesters who do not comply with the set management activities. Despite this, participants stated that these activities are not effective. A similar finding were traditional management strategies for healing plants was declared useless was reported in Zimbabwe (Mukamuri and Kozanayi 2001). Therefore, a joint endeavor for wild medicinal plants management amongst THs, harvesters and local conservation officials from the government might be helpful.

The public's lack of understanding regarding conservation legislation is a barrier to their effective implementations in the management of plants resources and ultimately a threat to biodiversity conservation. In the current study none of the interviewed THs had any knowledge of both national (National Environmental Management: Biodiversity Act No. 10 of 2004) and local (Limpopo Environmental Management Act No. 7 of 2003) conservation legislation, a comparable finding was reported by Moeng (2010) and Mathibela (2013) amongst muthi sellers and THs respectively in the Limpopo Province. Overall THs lack of knowledge about conservation legislation in this study might be attributed to a lack of public awareness initiatives by local conservation authorities focusing on these legislations, and or THs' limited ability to comprehend legislative documents due to lack of educational skills particularly reading. Nevertheless, until THs and other local resource harvesters are capacitated with knowledge of conservation legislation (including their values), effective management of medicinal plants in the Limpopo Province and other natural resources through legislation initiatives will remain a challenge.

Similarly, THs knowledge regarding the threatened and protected species was extremely low in this study. As expected all THs only knew that Brackenridgea zanguebarica was threatened, although they did not know which legislations are protecting it. This finding was anticipated mainly because the species is popular medicine and highly demanded across South Africa (Tshisikhawe 2002), coupled with the fact that it's localized in one area of Limpopo Province in the whole country. These factors make it easier for the harvester to know every single detail about the species including its legal status. For instance, interviewed Bapedi THs (irrespective of whether they mentioned $B$. zanguebarica or not) were quite aware of its status and associated penalties attached to its illegal harvesting. Therefore, awareness of the status of other species of conservation concerns and related legal obligations including penalties might lift the THs level of knowledge of their status. This awareness can be initiated via word of mouth (using local languages) at local 
community and THs meetings as well as media stations (i.e., radios and televisions).

In conclusion, the current study contributes to very limited literature that addresses harvesting practices, conservation status and factors threatening indigenous plants implicated in the treatment of RIs and RSs in South Africa and elsewhere. This survey clearly shows that traditional rituals play an important role amongst Bapedi THs prior harvesting of healing plant materials. However, both frequencies and volumes of collecting these materials by Bapedi THs, which they claim is motivated by harvesting counterparts (muthi traders and foreign harvesters) who harvest both indiscriminately and destructively, potentially cause a significant threat to the existence of targeted individual species and the entire population. Similarly, their techniques of obtaining undergrounds plant parts and whole plant from free access communal lands is extraordinarily destructive and might swiftly wipe-out the whole population. Sustainable harvesting techniques by interviewed THs were mainly observed when obtaining undergrounds parts from species found in homegardens. Likewise, same techniques were employed for collecting bark, leaf, twig and seed of plants distributed in the wilderness. Therefore, such sustainable harvesting techniques should be promoted amongst all the local medicinal plants harvesters (i.e., community members, healers, and muthi traders) and also incorporated into the provincial medicinal plant harvesting guidelines. However, the extensive illegitimate harvesting and utilization of protected and threatened medicinal plant species by Bapedi THs calls for urgent conservation measures to avoid their extinction. Educating THs and other local harvesters about these plant species and the value of conserving them should be a first conservation initiative. All threatening factors to the medicinal plants reported by interviewees need to be addressed or alternatives solutions be made, to avoid the rapid disappearance of wild medicinal plants especially those that are of conservation concern.

\section{ACKNOWLEDGEMENTS}

The authors are grateful to all Pedi Speaking traditional healers who shared their valuable knowledge of sources, harvesting, conservation status, threats and management of indigenous plant they use for respiratory infections and related symptoms in Limpopo Province, South Africa. This work was financially supported by the South African National Research Foundation (NRF), and Govan Mbeki Research and Development Centre (GMRDC), University of Fort.

\section{REFERENCES}

Abebe D, Ayehu A. 1993. Medicinal plants and enigmatic health practices of Northern Ethiopia. Health and Fitness, Addis Ababa.

Adams C. 2013. Mapping the knowledge economy of medicinal plants in Northern Madagascar: Information and resource flow in traditional health practices. digitalcollections.sit.edu/isp. [12 May 2017]
Akerele O, Heywood V, Synge H. 1991. The Conservation of Medicinal Plants. Cambridge University Press, Cambridge, UK.

Alam A, Iqba M, Vats, S. 2013. Cultivation of some overlooked bulbous ornamentals: A review on its commercial viability. Rep Op 5: 9-34

Attwell C, Cotterill F. 2000. Post modernism and African conservation science. Biodivers Conserv 9: 559-577.

Augustino S, Gillah, PR. 2005. Medicinal plants in urban districts of Tanzania: Plants, gender roles and sustainable use. Intl For Rev 7: 4458.

Bellewang EN. 2005. Socio-economic impact of Prunus africana management in the Mount Cameroon region: Case study of the Bokwoango community. [Thesis]. Royal Institute of Technology, Stockholm, Sweden.

Bodeker G, Van Klooster C, Weisbord E. 2014. Prunus africana (Hook.f.) Kalkman: The overexploitation of a medicinal plant species and its legal context. J Altern Complement Med 20: 810-822.

Botha J, Witkowski ETF, Shackleton CM. 2004. Market profiles and trade in medicinal plants in the lowveld, South Africa. Environ Conserv 31: 38-46.

Bruschi P, Mancini M, Mattioli E, Morganti M, Signorini MA. 2014. Traditional uses of plants in a rural community of Mozambique and possible links with Miombo degradation and harvesting sustainability. J Ethnobiol Ethnomed 10: 59. DOI: 10.1186/1746-4269-10-59.

Bukuluki P, Luwangula R, Walakira EJ. 2014. Harvesting of medicinal plants in Uganda: Practices, conservation and implications for the sustainability of supplies. Intl J Med Plants Res 3:1-10.

Capricorn District Municipality. 2013-2014. Integrated development plans and budget: 2013/2014. Capricorn District Municipality, Polokwane.

Chakravarty S, Ghosh SK, Suresh CP, Dey AN, Shukla G. 2011. Deforestation: Causes, effects and control strategies. http://www.intechopen.com. [13 March 2017].

Chapeyama O. 2009. Conservation and Sustainable Use of Traditional Medicinal Plants in Zimbabwe. Technical Report. Environment Management Agency, Zimbabwe. Harare.

Chavunduka GL. 1994. Traditional medicine in modern Zimbabwe. University of Zimbabwe Press, Harare.

Coopoosamy RM, Naidoo KK. 2012. An ethnobotanical study of medicinal plants used by traditional healers in Durban, South Africa. Afr J Pharm Pharmacol 6: 818-823.

Cunningham AB. 1993. African Medicinal Plants: setting priorities at the interface between conservation and primary health care. Working paper 1. UNESCO, Paris.

Cunningham AB. 2001. Applied Ethnobotany: People, Wild Plant Use and Conservation. Earth scan, London.

Dold AP, Cocks ML. 2002. The trade in medicinal plants in the Eastern Cape Province, South Africa. S Afr J Sci 98: 589-597.

Geldenhuys CJ, Williams VL. 2005. Impact of uncontrolled bark harvesting on the resource base: Trees for health-forever. In: Regional workshop of on implementing sustainable medicinal bark use in Southern Africa. Johannesburg, South Africa, 1-3 November 2005

Golding, J. 2002. Southern African Plant Red Data Lists. Southern African Botanical Diversity Network Report No. 14. SABONET, Pretoria.

Hamilton AC. 2004. Medicinal plants, conservation, and livelihoods. Biodivers Conserv 13: 1477-1517.

Ita PB, Offiong EE. 2013. Medicinal plants used in traditional medicine by rural communities in Cross River State, Nigeria. J Heal Med Nurs 1: 23-29.

Kadzere I, Hove L, Gatsi T, Masarirambi MT, Tapfumaneyi L, Maforimbo E, Magumise I. 2004. Current status of post-harvest handling and traditional processing of indigenous fruits in Zimbabwe. World Agroforestry Centre, Nairobi, Kenya.

Kambizi L, Afolayan AJ. 2006. Indigenous knowledge and its impact on medicinal plant conservation in Guruve, Zimbabwe. Indilinga 5: 26-31.

Khumalo CG, Fröde A, Sola P. 2016. Guidelines for the Sustainable Harvesting of Traditional Medicinal Plants in Zimbabwe. Milton Park Harare, Zimbabwe. http://projects.nri.org. [12 May 2017].

Kipkemoi NR, Kariuki NP, Wambui NV, Justus O, Kahia J. 2013. Micropropagation of an endangered medicinal plant, Strychnos henningsii (gilg), (loganiaceae) for sustainable conservation. Int J Med Plants Res 2: 247-253.

Kisangau DP, Herrmann TM, Lyaruu HVM, Hosea KM, Joseph CC, Mbwambo ZH, Masimba PJ. 2011. Traditional knowledge, use practices and conservation of medicinal plants for HIV/AIDS care in rural Tanzania. Ethnobot Res Appl 9: 43-57. 
Koduru S, Grierson DS, Afolayan AJ. 2007. Ethnobotanical information of medicinal plants used for the treatment of cancer in the Eastern Cape Province, South Africa. Curr Sci 92: 906-908.

Kokwaro JO. 1991. Conservation of medicinal plants in Kenya. In: Akerele O, Heywood V, Synge H (eds.), Conservation of medicinal plants. Cambridge University Press, Cambridge, UK.

Law W, Salick EJ. 2007. Comparing conservation priorities for useful plants among botanists and Tibetan doctors. Biodivers Conserv 16: 1747-1759.

Loundou P. 2008. Medicinal plants and opportunities for sustainable management in the Cape Peninsula, South Africa. [Thesis]. University of Stellenbosch, Western Cape.

Lulekal E, Kelbessa E, Bekele T, Yineger H. 2008. An ethnobotanical study of medicinal plants in Mana Angetu District, Southeastern Ethiopia. J Ethnobiol Ethnomed 4: 10 DOI: 10.1186/1746-4269-4-10.

Mabogo DEN. 1990. The ethnobotany of the VhaVenda. [Thesis] University of Pretoria, Pretoria.

Magoro MD. 2008. Traditional health practitioners' practices and the sustainability of extinction-prone traditional medicinal plants. [Thesis]. University of South Africa, Pretoria.

Mahwasane ST, Middleton N, Boaduo N. 2013. An ethnobotanical survey of indigenous knowledge on medicinal plants used by the traditional healers of the Lwamondo area, Limpopo Province, South Africa. S Afr J Bot 88: 69-75.

Makueti JT, Tsobeng A, Tchoundjeu Z, Tsafack S, Numbissi F. 2015 Population structure and traditional management patterns of two threatened medicinal tree species (Garcinia lucida and Pausinystalia johimbe) in the humid southern forest of Cameroon. J Biodivers Environ Sci 7: 459-481.

Mander M. 1998. Medicinal plant marketing in Bushbuckridge and Mpumalanga: A market survey and recommended strategies for sustaining the supply of plants in the region. Darudec and DWAF, South Africa.

Manzini TZ. 2005. Production of wild ginger (Siphonochilus aethiopicus) under protection and indigenous knowledge of the plant from traditional healers. [Dissertation]. University of Pretoria, Pretoria.

Maroyi A. 2013. Warburgia salutaris (Bertol.f.) Chiov.: A multi-use ethnomedicinal plant species. J Med Plants Res 7: 53-60.

Marshall NT. 1998. Searching for a cure: Conservation of medicinal wildlife resources in East and Southern Africa. TRAFFIC International. Cambridge, UK.

Mathibela MK. 2013. An investigation into aspects of medicinal plant use by traditional healers from Blouberg Mountain, Limpopo Province, South Africa. [Dissertation]. University of Limpopo, Mankweng.

Moeng ET. 2010. Analysis of Muthi shops and street vendors on medicinal plants of the Limpopo Province. [Thesis]. University of Limpopo, Mankweng.

Monakisi CM. 2007. Knowledge and use of traditional medicinal plants by the Setswana - speaking community of Kimberley, Northern Cape of South Africa. [Thesis]. University of Stellenbosch, Western Cape.

Mucina L, Rutherford MC. 2006. The vegetation of South Africa, Lesotho and Swaziland. South African National Biodiversity Institute, Pretoria

Mukamuri BB, Kozanayi W. 2001. Commercialization and institutional arrangements involving tree species harvested for bark by smallholder farmers in Zimbabwe. University of Zimbabwe, Harare, Zimbabwe.

Muthaura CN, Rukunga GM, Chhabra SC, Mungai GM, Njagi ENM, 2007. Traditional antimalarial phytotherapy remedies used by the Kwale community of the Kenyan Coast. J Ethnopharmacol 114: 377 386.

Naidoo E, Nyakale M. 2000. Muthi plants our heritage-our health Department of Agriculture, Conservation Environment and Land Affairs. Gauteng, South Africa.

Nanyingi MO, Mbaria JM, Lanyasunya AL, Wagate CG, Koros KB, Kaburia HW, Munenge RW, Ogara WO. 2008 Ethnopharmacological survey of Samburu district, Kenya. J Ethnobiol Ethnomed 4:14 . DOI: 10.1186/1746-4269-4-14.

National Environmental Management: Biodiversity Act (NEM:BA). 2004. (Act No. 107 of 2004). Government Gazette. Cape Town.

National Forest Act (NFA). 1998. (Act No. 84 of 1998), Government Communication and Information System. Government Gazette. Cape Town, South Africa.

Ndawonde BG. 2006. Medicinal Plant Sales: A Case Study in Northern Zululand. [Thesis]. University of Zululand, KwaDlangezwa.
Njoroge GN, Kaibui IM, Njenga PK, Odhiambo PO. 2010. Utilisation of priority traditional medicinal plants and local people's knowledge on their conservation status in arid lands of Kenya (Mwingi District). J Ethnobiol Ethnomed 6: 22 DOI: 10.1186/1746-4269-6-22.

Nzue APM. 2009. Use and conservation status of medicinal plants in the Cape Peninsula, Western Cape Province of South Africa. [Thesis]. University of Stellenbosch, Western Cape.

Okia CA, Agea JG, Kimondo MJ, Abohassan RAA, Obua J, Teklehaimanot Z. 2011. Harvesting and processing of Balanites aegyptiaca leaves and fruits for local consumption by rural communities in Uganda. J Food Technol 9: 83-90.

Omogbadegun Z, Uwadia C, Ayo C, Mbarika V, Omoregbe N, Otofia E, Chieze F. 2011. Multimedia- based medicinal plants sustainability management system. Int Comput Sci Issues 8: 492-503.

Petersen L. 2014. Cape Town's trade in wild medicines: Ecological threat or essential livelihood resource? Sustainable Livelihoods Foundation. http://www.econ3x3.org. [12 May 2017]

Plantzafrica. 2017. Vernonia natalensis Sch. Bip. ex Walp. http://www.plantzafrica.com. [12 May 2017]

Quinlan, M. 2005. Considerations for collecting free lists in the field: Examples from ethnobotany. Field Meth 17: 1-16.

Rakuambo ZJ. 2007. Indigenous knowledge of bush tea (Athrixia phylicoides) and effect of fertigation frequency and growing medium on plant growth. [Thesis]. University of Pretoria, Pretoria.

Ramakrishnappa K. 2002. Impact of cultivation and gathering of medicinal plants on biodiversity: Case studies from India. Food and Agriculture Organization, Rome.

Rampedi IT. 2010. Indigenous plants in the Limpopo Province: Potential for Their Commercial Beverage Production. [Dissertation]. University of South Africa, Pretoria.

Rasethe MT. 2017. The utilisation and management of selected TopSpecies in the Limpopo Province, South Africa. [Thesis]. University of Limpopo, Mankweng.

Rautenbach C, Walton N, Van Nierop M. 2006. Capricorn District Municipality Air Quality Management Plan. Gondwana Environmental Solutions (Pty) Ltd, Randburg.

Sekhukhune District Municipality. 2008. Development of an air quality management plan for the Greater Sekhukhune district municipality. Sekhukhune district municipality, Groblersdal.

Semenya, S.S. 2012. Bapedi phytomedicine and their use in the treatment of sexually transmitted diseases in Limpopo Province, South Africa. [Thesis]. University of Limpopo, Mankweng.

Shanley P, Luz L. 2003. The impacts of forest degradation on medicinal plant use and implications for health care in Eastern Amazonia. BioSci 53: 573-584.

South Africa National Biodiversity Institute (SANBI). 2017. The IUCN Categories and Criteria version 3.1. SANBI, Pretoria.

Statistic South Africa. 2011. Limpopo demographic profile. Statistic South Africa, Pretoria.

Street RA, Prinsloo G. 2013. Commercially important medicinal plants of South Africa: A review. J Chem. DOI: 10.1155/2013/205048.

Struhsaker TT. 1998. A biologist's perspective on the role of sustainable harvest in conservation. Conser Biol 12: 930-932.

Thring TSA, Weitz, FM. 2006. Medicinal plant use in the Bredasdorp/Elim region of the Southern Overberg in the Western Cape Province of South Africa. J Ethnopharmacol 103: 261-275.

Tshisikhawe MP. 2012. An ecological evaluation of the sustainability of bark harvesting of medicinal plant species in the Venda region, Limpopo province, South Africa. [Dissertation]. University of Pretoria, Pretoria.

Tshisikhawe NP. 2002. Trade of Indigenous Medicinal Plants in the Northern Province, Venda Region: Their Ethnobotanical Importance and Sustainable Use. [Thesis]. University of Venda, Thohoyandou.

Victor J, Siebert S, Hoare D, Wyk, BV. 2005. Sekhukhuneland Grasslands: A Treasure House of Biodiversity. FAO, Rome.

Victor JE, Keith M. 2004. The orange list: A safety net for biodiversity in South Africa. S Afr J Sci 100: 139-141.

Wangchuk P, Olsen A. 2010-2011. Risk factors for the sustainability of medicinal plants in Bhutan. Asian Med 6: 123-36.

Warburton H, Martin A. 1999. Local people's knowledge in natural resources research. Socio-economic Methodologies for Natural Resources Research. Natural Resources Institute, Chatham, UK.

Waterberg District Municipality. 2014-2015. Integrated development plant 2014-2015. Waterberg District Municipality, Modimolle. 
Wilder T, Edholm S. 2008. Sustainable Harvest:Approaching wildcrafting with knowledge and intent. Boonville, CA. www.paleotechnics.com. [17 April 2017]

Williams VL, Balkwill K, Witkowski ETF. 2001. A lexion of plant traded in the Witwatersrand umuthi shops, South Africa. Bothalia 31: 71-98.
Williams VL, Victor JE, Crouch NR. 2013. Red Listed medicinal plants of South Africa: Status, trends, and assessment challenges. S Afr J Bot 86: 23-35.

Zschocke D, Rabe T, Taylor JLS, Van Staden J. 2000. Plant part substitution-a way to conserve endangered medicinal plants? J Ethnopharmacol 71: 281-292. 
Table S1. Medicinal plant species used to treat respiratory infections and related symptoms in the studied districts and municipalities

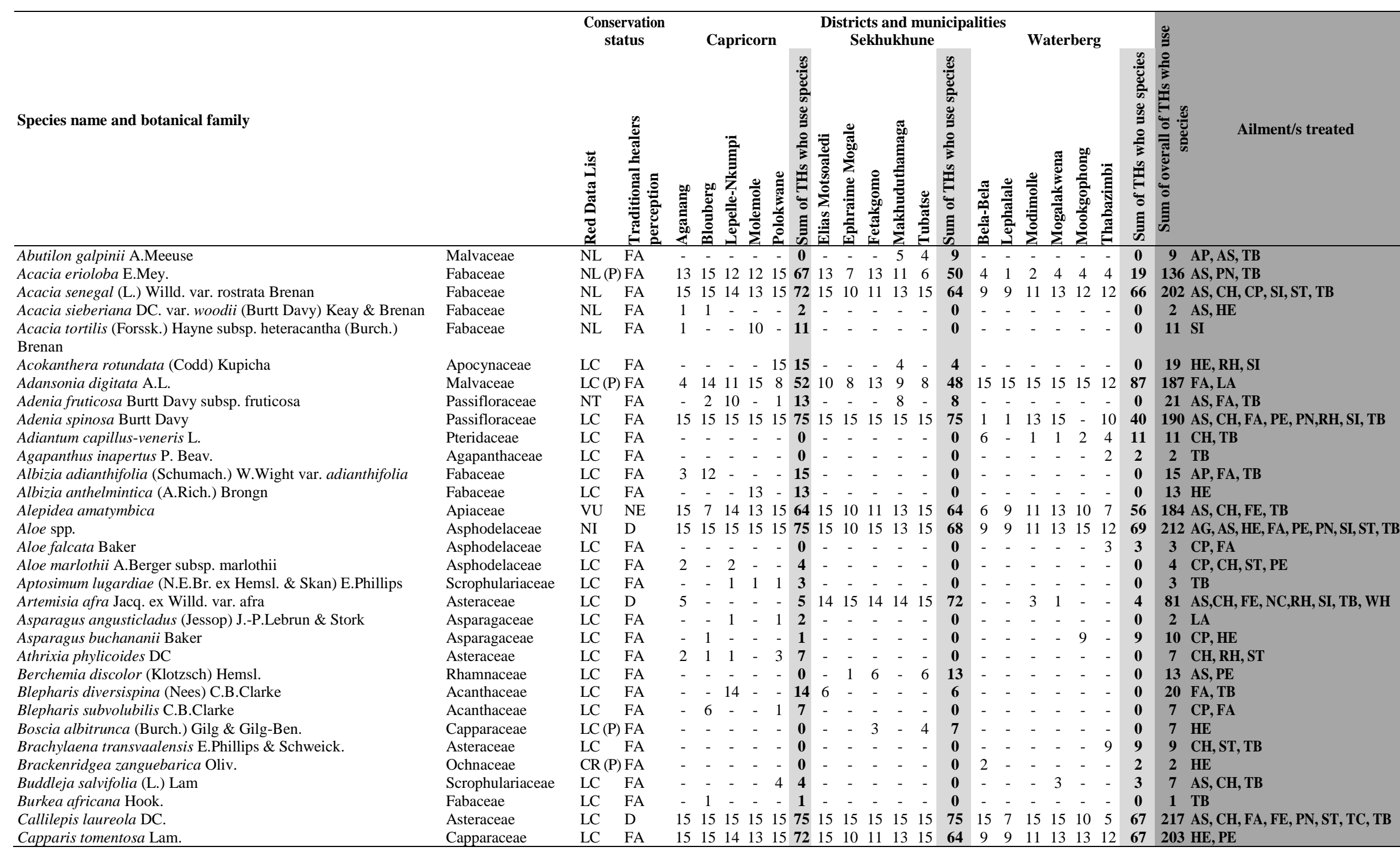




\begin{tabular}{|c|c|c|c|c|c|c|c|c|c|c|c|c|c|c|c|c|c|c|c|c|c|c|c|c|}
\hline Carissa bispinosa (L.) Desf. ex Brenan & Apocynaceae & $\mathrm{LC}$ & FA & 5 & 8 & 1 & 8 & & 23 & & - & - & - & - & $\mathbf{0}$ & - & - & - & - & - & - & $\mathbf{0}$ & 23 & AG, CH, CP, LA, SI, TB \\
\hline Carpobrotus edulis (L.) L.Bolus subsp. edulis & Mesembryanthemacea & eLC & FA & 15 & 15 & 15 & 15 & & 741 & 15 & 11 & 9 & - & 1 & 36 & 8 & 12 & 5 & 8 & 9 & 5 & 47 & 157 & AS, AP, LA, ST, TB \\
\hline Cassia abbreviata Oliv. subsp. beareana (Holmes) Brenan & Fabaceae & $\mathrm{LC}$ & FA & 15 & - & 1 & - & 2 & 18 & - & - & - & - & - & $\mathbf{0}$ & - & - & - & - & - & - & $\mathbf{0}$ & 18 & AS, CH, FA, ST, LA, PN \\
\hline Cassinopsis ilicifolia (Hochst.) Kuntze & Icacinaceae & $\mathrm{LC}$ & FA & 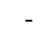 & - & - & - & - & $\mathbf{0}$ & . & 12 & - & - & - & $\mathbf{0}$ & - & - & - & - & - & - & $\mathbf{0}$ & 12 & FA, TB \\
\hline \multirow[t]{2}{*}{ Cassipourea garcini (Shinz) Alstroron } & Rhizophoraceae & $\mathrm{LC}$ & $\mathrm{D}$ & 15 & 15 & 15 & - & - & 45 & - & - & - & - & - & $\mathbf{0}$ & - & - & - & - & - & - & $\mathbf{0}$ & 45 & LA \\
\hline & & & FA & 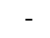 & - & & 15 & & & 15 & 10 & & & & 64 & 9 & 9 & 11 & & 12 & 12 & 66 & 160 & \\
\hline Catha edulis (Vahl) Forssk. ex Endl. & Celastraceae & $\mathrm{LC}(\mathrm{P})$ & FA & 15 & 15 & 15 & 15 & 15 & 751 & 15 & 15 & 15 & 15 & 15 & 75 & 15 & 15 & 15 & 15 & 15 & 15 & 90 & 240 & FA, LA \\
\hline Citrullus lanatus (Thunb.) Matsum. \& Nakai & Cucurbitaceae & $\mathrm{LC}$ & FA & 15 & 15 & 14 & 13 & 15 & 721 & 15 & 10 & 11 & 13 & 15 & 64 & 9 & 9 & 11 & 13 & 12 & 12 & 66 & 202 & $\mathrm{HE}$ \\
\hline Clematis brachiata Thunb. & Ranunculaceae & $\mathrm{LC}$ & FA & - & - & - & - & - & $\mathbf{0}$ & 4 & 2 & 4 & 1 & 4 & 15 & - & - & - & - & - & - & $\mathbf{0}$ & 15 & HE, SI \\
\hline Cleome gynandra $\mathrm{L}$. & Capparaceae & $\mathrm{LC}$ & FA & - & - & - & - & - & $\mathbf{0}$ & - & - & - & - & - & $\mathbf{0}$ & 1 & - & - & - & - & - & 1 & 1 & RH \\
\hline Clerodendrum glabrum E.Mey. var. angustifolium E.Mey. & Lamiaceae & NL & FA & 1 & 5 & 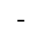 & - & 15 & 21 & - & 5 & - & 1 & - & 6 & 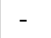 & - & . & 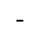 & . & - & $\mathbf{0}$ & 27 & AG, AP, AS, CH, SI, ST, TB \\
\hline Clerodendrum ternatum Schinz & Lamiaceae & $\mathrm{LC}$ & $\mathrm{D}$ & 15 & 15 & 15 & 15 & 15 & 751 & 15 & 15 & 15 & 15 & 15 & 75 & 15 & 15 & 15 & 15 & 15 & 15 & 90 & 240 & AS, CH, PN, RH, SI, ST, TB \\
\hline Clivia caulescens R.A.Dyer & Amaryllidaceae & NT & FA & - & - & - & 7 & - & 7 & - & - & - & - & - & $\mathbf{0}$ & - & - & - & - & - & - & $\mathbf{0}$ & 7 & AS, LA \\
\hline Combretum hereroense Schinz subsp. Hereroense & Combretaceae & NL & FA & 15 & 15 & 14 & 13 & 15 & 721 & 15 & 10 & 11 & 13 & 15 & 64 & 9 & 9 & 11 & 13 & 12 & 12 & 66 & 202 & TB \\
\hline Combretum zeyheri Sond & Combretaceae & $\mathrm{LC}$ & FA & - & 1 & - & - & - & 1 & - & 1 & - & - & 1 & 2 & - & - & - & - & - & - & $\mathbf{0}$ & 3 & CH, HE, LA \\
\hline Commelina africana L. var. Africana & Commelinaceae & $\mathrm{LC}$ & FA & - & - & - & - & 1 & 1 & - & - & - & - & - & $\mathbf{0}$ & - & - & - & - & - & - & $\mathbf{0}$ & 1 & PE \\
\hline Commelina subulata Roth & Commelinaceae & LC & FA & - & - & - & - & - & $\mathbf{0}$ & - & - & - & - & - & $\mathbf{0}$ & - & - & - & - & 1 & - & 1 & 1 & HE \\
\hline Commiphora marlothii Engl. & Burseraceae & $\mathrm{LC}$ & FA & 1 & 1 & 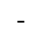 & - & - & 2 & - & - & - & - & - & $\mathbf{0}$ & - & - & . & 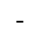 & 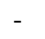 & - & 0 & 2 & $\mathbf{C H}, \mathbf{R H}$ \\
\hline \multirow{2}{*}{ Croton gratissimus Burch. var. gratissimus } & Euphorbiaceae & $\mathrm{LC}$ & $\mathrm{D}$ & . & - & 12 & - & - & 12 & 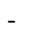 & - & - & - & - & $\mathbf{0}$ & - & - & - & 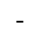 & - & - & $\mathbf{0}$ & 12 & AS, NC, SI, ST, TB, WH \\
\hline & & & FA & 15 & 15 & 3 & 15 & 15 & 631 & 15 & 15 & 15 & 15 & 15 & 75 & 15 & 15 & 15 & 15 & 15 & 15 & 90 & 228 & \\
\hline Croton menyharthii Pax & Euphorbiaceae & $\mathrm{LC}$ & FA & - & - & - & - & 1 & 1 & - & - & 8 & - & 2 & 10 & - & - & - & - & - & - & $\mathbf{0}$ & 11 & CH, PE, TB \\
\hline Cryptocarya transvaalensis Burtt Davy & Lauraceae & $\mathrm{D}$ & FA & 15 & 15 & 15 & 15 & 15 & 751 & 15 & 15 & 15 & 15 & 15 & 75 & 15 & 15 & 15 & 15 & 15 & 15 & 90 & 240 & AS, CH, CP, FE, PN, RH, SI, ST, TB \\
\hline Cucumis metuliferus E.Mey. ex Naudin & Cucurbitaceae & $\mathrm{LC}$ & FA & - & - & - & - & - & 0 & 3 & - & 9 & 6 & 1 & 19 & - & - & - & - & - & - & $\mathbf{0}$ & 19 & AS, TB \\
\hline Cucumis zeyheri Sond. & Cucurbitaceae & $\mathrm{LC}$ & FA & - & 1 & - & 6 & 5 & 12 & - & 5 & - & - & - & 5 & - & - & - & - & - & - & $\mathbf{0}$ & 17 & LA, TB \\
\hline Cyperus sexangularis Nees & Cyperaceae & $\mathrm{LC}$ & FA & 15 & 15 & 15 & 15 & 15 & 751 & 15 & 12 & 15 & 12 & 9 & 63 & 1 & 1 & 3 & 2 & 15 & 10 & 32 & 170 & AS, FA, FE, PN, TB \\
\hline $\begin{array}{l}\text { Cyphostemma humile (N.E.Br.) Desc. ex Wild \& R.B.Drumm. } \\
\text { subsp. humile }\end{array}$ & Vitaceae & $\mathrm{LC}$ & FA & - & - & - & - & 1 & 1 & 3 & - & - & - & 1 & 4 & - & - & - & - & - & - & $\mathbf{0}$ & 5 & TB, PN \\
\hline Cyphostemma woodii (Gilg \& M.Brandt) Desc. & Vitaceae & LC & FA & - & - & - & - & - & $\mathbf{0}$ & 1 & - & - & - & - & 1 & - & - & - & - & - & - & $\mathbf{0}$ & 1 & TB \\
\hline Dicerocaryum senecioides (Klotzsch) Abels & Pedaliaceae & $\mathrm{LC}$ & FA & - & - & - & - & - & $\mathbf{0}$ & - & - & - & - & - & $\mathbf{0}$ & - & - & 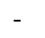 & - & 13 & - & 13 & 14 & AS, CH, TB \\
\hline $\begin{array}{l}\text { Dichrostachys cinerea }(\text { L.) Wight \& Arn. subsp. africana Brenan } \\
\& \text { Brummitt var. Africana }\end{array}$ & Fabaceae & $\mathrm{LC}$ & FA & 15 & 10 & 14 & 13 & 15 & 671 & 15 & 10 & 11 & 13 & 15 & 64 & 9 & 9 & 11 & 13 & 12 & 12 & 66 & 197 & TB \\
\hline \multirow[t]{3}{*}{ Dicoma anomala subsp. gerrardii } & Asteraceae & $\mathrm{LC}$ & $\mathrm{D}$ & - & - & 10 & - & - & 10 & - & - & - & - & - & $\mathbf{0}$ & - & - & - & - & - & - & $\mathbf{0}$ & 10 & AS, ST, TB \\
\hline & & & FA & 15 & 15 & 4 & 14 & 13 & 611 & 15 & 10 & 11 & 13 & 15 & 64 & 9 & - & - & 13 & - & 12 & 34 & 159 & \\
\hline & & & $\mathrm{NE}$ & 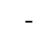 & - & - & - & - & $\mathbf{0}$ & . & - & . & - & & $\mathbf{0}$ & - & 12 & 11 & - & 13 & . & 36 & 36 & \\
\hline Dioscorea dregeana (Kunth) T.Durand \& Schinz & Dioscoreaceae & LC & FA & 1 & - & - & - & - & 1 & - & - & - & - & - & $\mathbf{0}$ & - & - & - & - & - & - & $\mathbf{0}$ & 1 & PN, TB \\
\hline Dioscorea sylvatica Eckl. & Dioscoreaceae & VU & $\mathrm{NE}$ & 1 & _- & 2 & - & . & 31 & 15 & 10 & 11 & 15 & 15 & 66 & - & 1 & 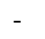 & - & - & 3 & 4 & 73 & AS, AP, TB \\
\hline Diospyros lycioides Desf. subsp. sericea (Bernh.) De Winter & Ebenaceae & $\mathrm{LC}$ & FA & 15 & 15 & 14 & 13 & 15 & 721 & 15 & 10 & 11 & 13 & 15 & 64 & 9 & 9 & 11 & 13 & 12 & 12 & 66 & 202 & $\mathrm{HE}$ \\
\hline Diospyros mespiliformis Hochst. ex A.DC & Ebenaceae & $\mathrm{LC}$ & FA & - & - & - & - & - & $\mathbf{0}$ & 9 & - & - & - & - & 9 & - & - & - & - & - & - & $\mathbf{0}$ & 9 & TB \\
\hline Dodonaea viscosa Jacq. var. angustifolia (L.f.) Benth. & Sapindaceae & $\mathrm{LC}$ & FA & 1 & - & 11 & - & - & 12 & - & - & - & - & - & $\mathbf{0}$ & - & - & - & - & - & - & $\mathbf{0}$ & 12 & LB, TB \\
\hline Dombeya rotundifolia (Hochst.) Planch. var. rotundifolia & Malvaceae & $\mathrm{LC}$ & FA & 1 & 1 & 1 & 1 & 5 & 9 & 3 & 4 & 1 & - & 1 & 9 & - & - & - & - & - & - & $\mathbf{0}$ & 18 & FA, HE, LA, PN, ST \\
\hline \multirow[t]{2}{*}{ Drimia elata Jacq. } & Hyacinthaceae & DDT & $\mathrm{D}$ & 5 & 9 & 2 & - & 12 & 28 & 6 & - & - & - & - & 6 & - & - & - & 1 & 4 & 4 & 5 & 39 & AG, AS, CP, FA, PN, ST, TB, WH \\
\hline & & & $\mathrm{NE}$ & - & - & - & - & - & $\mathbf{0}$ & - & - & - & - & - & $\mathbf{0}$ & - & - & 3 & - & 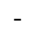 & - & 3 & 3 & \\
\hline inea (Schinz) Jessop & Hya & NT (P) & & 3 & - & - & - & . & 3 & 1 & 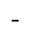 & - & 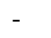 & - & 1 & - & - & . & - & - & - & $\mathbf{0}$ & 4 & CP, PN, TB \\
\hline $\begin{array}{l}\text { Ehretia rigida (Thunb.) Druce subsp. silvatica Retief \& A.E.van } \\
\text { Wyk }\end{array}$ & Boraginaceae & $\mathrm{LC}$ & FA & - & 1 & - & - & - & 1 & - & - & - & - & - & $\mathbf{0}$ & - & - & - & - & - & - & $\mathbf{0}$ & 1 & HE \\
\hline Elaeodendron transvaalense (Burtt Davy) R.H.Archer & Celas & NT (P) & FA & - & - & 2 & - & - & 2 & - & & - & - & - & $\mathbf{0}$ & - & - & - & - & - & - & $\mathbf{0}$ & 2 & CP, CH \\
\hline \multirow[t]{3}{*}{ Elephantorrhiza burkei Benth. } & Fabaceae & $\mathrm{LC}$ & D & - & - & - & - & 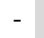 & $\mathbf{0}$ & - & - & - & - & - & 0 & 2 & - & 1 & - & - & 4 & 7 & 7 & AS, FA, TB \\
\hline & & & FA & - & 2 & - & - & 1 & 3 & - & - & - & & 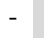 & 0 & - & - & - & - & 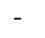 & - & 0 & 3 & \\
\hline & & & $\mathrm{NE}$ & - & - & - & - & 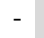 & $\mathbf{0}$ & - & - & 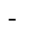 & - & 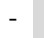 & $\mathbf{0}$ & 2 & - & - & - & - & - & 2 & 2 & \\
\hline \multirow[t]{2}{*}{ Elephantorrhiza goetzei (Harms) Harms subsp. goetzei } & Fabaceae & LC & D & - & - & - & - & 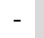 & $\mathbf{0}$ & - & - & 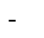 & - & - & 0 & - & 5 & & & & & 5 & 5 & $\mathrm{CH}, \mathrm{FA}$ \\
\hline & & & FA & - & 1 & - & - & - & 1 & - & 1 & - & - & - & 1 & - & - & - & - & - & - & 0 & 2 & \\
\hline
\end{tabular}




\begin{tabular}{|c|c|c|c|c|c|c|c|c|c|c|c|c|c|c|c|c|c|c|c|c|c|c|c|c|}
\hline Encephalartos transvenosus Stapf \& Burtt Davy & Zamiaceae & $\mathrm{LC}$ & FA & 15 & 15 & & 15 & 157 & & 4 & & 6 & 11 & 4 & 25 & - & 4 & - & 4 & 2 & - & $\mathbf{1 0}$ & 110 & FA, PN \\
\hline Englerophytum magalismontanum (Sond.) T.D.Penn. & Sapotaceae & $\mathrm{LC}$ & FA & - & 1 & 10 & - & - & 1 & 1 & 7 & 6 & 6 & 6 & 26 & 1 & - & - & 1 & - & 1 & 3 & 30 & AS, HE, PE \\
\hline Enicostema axillare (Lam.) A.Raynal subsp. Axillare & Gentianaceae & $\mathrm{LC}$ & $\mathrm{D}$ & 15 & 15 & 15 & 15 & & 75 & 15 & 15 & 15 & 15 & 15 & 75 & 15 & 15 & 15 & 15 & 15 & 15 & 90 & 240 & AS, PN, RH, SI, ST, TB \\
\hline Erythrina lysistemon Hutch. & Fabaceae & $\mathrm{LC}$ & FA & 8 & 3 & 5 & . & & 16 & 5 & - & - & - & - & 5 & - & - & - & - & 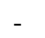 & . & $\mathbf{0}$ & 21 & CH, SI, ST, WH, TB \\
\hline Euclea crispa (Thunb.) Garke subsp. crispa & Ebenaceae & $\mathrm{LC}$ & FA & 1 & - & - & - & - & 1 & - & - & - & - & - & $\mathbf{0}$ & - & 2 & 1 & 3 & - & 3 & 9 & 10 & FA \\
\hline Euclea undulata Thunb. & Ebenaceae & $\mathrm{LC}$ & FA & - & - & - & - & - & $\mathbf{0}$ & - & - & 2 & - & - & 2 & - & - & - & - & - & - & $\mathbf{0}$ & 2 & TB \\
\hline Eucomis autumnalis (Mill.) Chitt. & Hyacinthaceae & $\mathrm{D}$ & $\mathrm{NE}$ & 1 & 1 & 8 & - & -1 & 10 & - & - & - & - & - & $\mathbf{0}$ & - & - & - & - & - & - & $\mathbf{0}$ & 10 & $\mathrm{FA}, \mathrm{NC}, \mathrm{TB}$ \\
\hline Eucomis pallidiflora Baker subsp. pole-evansii (N.E.Br.) Reyneke & Hyacinthaceae & NT & $\mathrm{D}$ & 15 & 15 & 15 & 15 & & 75 & 15 & 10 & 11 & 14 & 15 & 65 & 12 & 9 & - & 14 & 13 & 14 & 62 & 202 & AG, CP, CH, FA, NC, SI, ST, WH \\
\hline ex J.C.Manning & & & $\mathrm{NE}$ & - & - & - & - & - & $\mathbf{0}$ & - & - & - & - & - & $\mathbf{0}$ & - & - & 14 & - & - & - & 14 & 14 & \\
\hline Euphorbia inaequilatera Sond. var. inaequilatera & Euphorbiaceae & NEV & FA & - & - & 1 & 4 & 1 & 6 & - & - & 2 & - & - & 2 & 2 & - & - & - & - & - & 2 & 10 & CP, RH, PE, PN \\
\hline Euphorbia schinzii Pax & Euphorbiaceae & $\mathrm{LC}$ & FA & - & - & 5 & 1 & 2 & 8 & 14 & 11 & 6 & 12 & 6 & 49 & - & - & - & 2 & - & 1 & 3 & 60 & AS, PE, RH, SI \\
\hline Ficus abutilifolia (Miq.) Miq. & Moraceae & $\mathrm{LC}$ & FA & - & - & - & - & - & $\mathbf{0}$ & 15 & 10 & 11 & 13 & 15 & 64 & - & - & - & - & - & - & $\mathbf{0}$ & 64 & TB \\
\hline Ficus burkei (Miq.) Miq. & Moraceae & $\mathrm{LC}$ & FA & - & 2 & - & - & - & 2 & - & - & - & - & - & $\mathbf{0}$ & - & - & - & - & - & - & $\mathbf{0}$ & 2 & $\mathrm{HE}$ \\
\hline Ficus ingens (Miq.) Miq & Moraceae & $\mathrm{LC}$ & FA & - & - & - & - & - & $\mathbf{0}$ & - & - & - & - & - & 0 & - & - & - & 1 & - & 13 & 14 & 14 & ST, TB \\
\hline Flueggea virosa (Roxb. ex Willd.) Voigt subsp. Virosa & Phyllanthaceae & $\mathrm{LC}$ & FA & - & 1 & - & - & - & 1 & - & - & - & - & 5 & 5 & - & - & - & - & - & $\ldots$ & $\mathbf{0}$ & 6 & PE \\
\hline Garcinia gerrardii Harv. ex Sim & Clusiaceae & $\mathrm{LC}$ & FA & - & - & - & - & - & $\mathbf{0}$ & - & - & - & - & - & 0 & - & - & - & - & - & 3 & 3 & 3 & $\mathrm{CH}, \mathrm{TB}$ \\
\hline Geigeria burkei Harv. subsp. burkei var. hirtella merxm & Asteraceae & NEV & FA & - & - & - & - & - & $\mathbf{0}$ & 1 & 3 & 4 & 6 & 6 & 20 & - & - & - & - & - & - & $\mathbf{0}$ & 20 & PE \\
\hline Gossypium herbaceum L. subsp. africa & Malvaceae & $\mathrm{LC}$ & $\mathrm{D}$ & - & - & - & - & - & $\mathbf{0}$ & 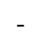 & - & 15 & 13 & - & 28 & - & - & - & - & - & - & $\mathbf{0}$ & 28 & AS, PN, TB \\
\hline & & & FA & 15 & 15 & 14 & 13 & & 72 & 15 & 14 & - & - & 15 & 44 & 9 & 9 & 11 & 15 & 15 & 15 & 74 & 190 & \\
\hline Grewia bicolor Juss & Malvaceae & $\mathrm{LC}$ & FA & - & - & - & - & - & $\mathbf{0}$ & . & - & - & - & 0 & $\mathbf{0}$ & - & - & - & - & - & 4 & 4 & 4 & LA, PE, TB \\
\hline Grewia flava DC. & Malvaceae & $\mathrm{LC}$ & FA & - & - & - & - & - & $\mathbf{0}$ & - & - & - & - & - & $\mathbf{0}$ & 9 & 9 & 11 & 13 & 12 & 12 & 66 & 66 & TB \\
\hline Grewia flavescens Juss. & Malvaceae & $\mathrm{LC}$ & FA & - & - & - & - & - & $\mathbf{0}$ & - & - & - & 1 & - & 1 & - & - & - & - & - & - & $\mathbf{0}$ & 1 & LA \\
\hline Grewia hispida Harv. & Malvaceae & $\mathrm{LC}$ & FA & - & - & 2 & - & - & 2 & 1 & - & - & - & - & 1 & - & - & - & - & - & - & $\mathbf{0}$ & 3 & $\mathrm{NC}, \mathrm{PE}$ \\
\hline Grewia occidentalis L. & Malvaceae & $\mathrm{LC}$ & FA & - & - & - & - & - & $\mathbf{0}$ & - & - & - & - & - & 0 & - & - & - & - & - & 6 & 6 & 6 & ST, TB \\
\hline Grewia sulcata Mast. var. sulcata & Malvaceae & $\mathrm{LC}$ & FA & - & - & - & - & - & 0 & - & 1 & _ & - & 2 & 3 & _ & - & - & _ & - & - & $\mathbf{0}$ & 3 & AS, HE \\
\hline Gymnosporia maranguensis (Loes.) Loes. & Celastraceae & $\mathrm{LC}$ & FA & - & - & - & - & - & 0 & 1 & 3 & 3 & 3 & 2 & 12 & 2 & ـ & - & 1 & 1 & 1 & 5 & 17 & HE, TB \\
\hline Gymnosporia pubescens (N.Robson) Jordaan & Celastraceae & $\mathrm{LC}$ & FA & - & - & - & - & - & $\mathbf{0}$ & 2 & - & - & - & - & $\mathbf{0}$ & - & - & - & - & - & 4 & 4 & 4 & CH, ST \\
\hline Gymnosporia senegalensis (Lam.) Loes. & Celastraceae & $\mathrm{LC}$ & FA & - & 2 & 4 & - & 2 & 8 & - & - & - & - & 1 & 1 & - & 1 & - & - & 3 & 3 & 7 & 16 & LA, PE, TB \\
\hline Harpephyllum caffrum Bernh. ex Krauss & Anacardiaceae & $\mathrm{LC}$ & FA & - & - & - & - & - & $\mathbf{0}$ & - & - & - & 6 & - & 6 & - & - & - & - & - & - & $\mathbf{0}$ & 6 & $\mathrm{AS}, \mathrm{CH}, \mathrm{HE}$ \\
\hline Helichrysum caespititium (DC.) Harv. & Asteraceae & $\mathrm{LC}$ & FA & 1 & - & - & - & - & 1 & - & 1 & - & - & - & 1 & - & - & - & - & - & - & $\mathbf{0}$ & 2 & FA, PN \\
\hline Helichrysum gymnocomum DC. & Asteraceae & \multicolumn{2}{|c|}{ Purchased } & - & - & - & - & - & 0 & - & - & - & - & - & 0 & - & - & - & - & - & - & $\mathbf{0}$ & 0 & AS, CP \\
\hline Helichrysum kraussii Sch.Bip. & Asteraceae & LC & FA & - & - & - & - & - & 0 & _ & 1 & - & - & - & 1 & - & - & - & _ & - & - & $\mathbf{0}$ & 1 & TB \\
\hline Heteromopha arbores & Apiaceae & $\mathrm{LC}$ & FA & - & - & _ & _ & 9 & 9 & _ & - & 4 & - & _ & 4 & _ & ـ & - & - & - & _ & $\mathbf{0}$ & 13 & LA, TB \\
\hline Hibiscus meyeri Harv. subsp. meyeri & Malvaceae & $\mathrm{LC}$ & FA & - & - & - & 3 & , & 3 & - & - & + & - & 6 & 6 & - & - & - & - & - & - & $\mathbf{0}$ & 9 & $\mathbf{P E}$ \\
\hline Hypoxis hemerocallidea Fisch., C.A.Mey. \& Avé-Lall & Hypoxidaceae & $\mathrm{D}$ & $\mathrm{D}$ & 2 & - & _ & 1 & 151 & 18 & _ & 2 & _ & 2 & - & 4 & _ & - & - & _ & - & - & $\mathbf{0}$ & 22 & AS, FA, ST, TB \\
\hline Hypoxis obtusa Burch. ex Ker Gawl. & Hypoxidaceae & $\mathrm{LC}$ & $\mathrm{D}$ & 2 & - & - & - & - & 2 & - & - & - & - & - & $\mathbf{0}$ & - & 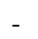 & - & 1 & 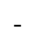 & - & 1 & 3 & FA, LA \\
\hline Indigofera circinnata Benth. ex Harv. & Fabaceae & $\mathrm{LC}$ & FA & - & - & - & 7 & - & 7 & 5 & 3 & 14 & - & - & 22 & - & - & - & - & - & 1 & 1 & 30 & CH, ST, LA \\
\hline Ipomoea albivenia (Lindl.) Sweet & Convolvulaceae & $\mathrm{LC}$ & FA & - & 2 & - & - & - & 2 & o & - & - & - & 4 & 4 & - & 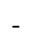 & - & - & - & - & $\mathbf{0}$ & 6 & AS, TB \\
\hline Jatropha zeyheri Sond. & Euphorbiaceae & $\mathrm{LC}$ & FA & 5 & 2 & - & - & - & 7 & - & - & - & - & - & o & - & - & - & - & - & - & $\mathbf{0}$ & 7 & AS, FA, PN, TB \\
\hline \multirow[t]{2}{*}{ Kalanchoe brachyloba Welw. ex Britten } & Crassulaceae & $\mathrm{LC}$ & $\mathrm{D}$ & - & - & _ & - & 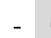 & o & _ & - & - & - & - & 0 & _ & . & - & _ & 11 & _ & 11 & 11 & HE, NC, SI \\
\hline & & & FA & 15 & 15 & 15 & 15 & & & 14 & 15 & 13 & 15 & 13 & 70 & 10 & 2 & 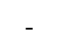 & 9 & 4 & 10 & 35 & 180 & \\
\hline Kirkia wilmsii Engl. & Kirkiaceae & $\mathrm{LC}$ & FA & 1 & - & 1 & 1 & 1 & 4 & . & - & 2 & - & 1 & 3 & - & - & - & 2 & - & - & 2 & 2 & AS, NC, TB \\
\hline Kleinia longiflora DC. & Asteraceae & $\mathrm{LC}$ & FA & 3 & - & - & t & 1 & 4 & 2 & 7 & 6 & 6 & 6 & 26 & 5 & 1 & - & 4 & 8 & 5 & 23 & 53 & CP, ST, PE, PN \\
\hline Lannea discolor (Sond.) Engl. & Anacardiaceae & $\mathrm{LC}$ & FA & - & - & - & - & 2 & 0 & - & - & - & - & - & 0 & - & 2 & - & - & - & - & 2 & 2 & CH \\
\hline Lantana rugosa $\mathrm{L}$ & Verbenaceae & $\mathrm{LC}$ & FA & - & - & - & - & - & $\mathbf{0}$ & - & - & - & - & - & 0 & . & 1 & 6 & 4 & 5 & 9 & 15 & 25 & AS, FE, ST, TB \\
\hline \multirow[t]{2}{*}{ Lasiosiphon caffer Meisn. } & Thymelaeacea & $\mathrm{LC}$ & $\mathrm{D}$ & - & 15 & 15 & 15 & 156 & 60 & 15 & 15 & 15 & 15 & 15 & 75 & 15 & 15 & 15 & 15 & 15 & 15 & 90 & 225 & AS, CH, CP, PN, RH, SI, ST, TC, \\
\hline & & & $\mathrm{NE}$ & 15 & 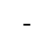 & . & - & & 15 & 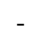 & . & - & - & . & $\mathbf{0}$ & . & 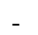 & - & 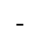 & & & $\mathbf{0}$ & 15 & TB \\
\hline Leonoti & $\mathrm{La}$ & $\mathrm{LC}$ & FA & - & - & - & _- & - & 0 & 3 & 2 & 2 & 11 & 1 & 19 & _- & - & ـ & - & - & _- & $\mathbf{0}$ & 19 & AS, CH \\
\hline Lippia javanica (Burm.f.) Spreng. & Verbenaceae & $\mathrm{LC}$ & FA & 15 & 15 & 15 & 15 & 157 & 75 & 15 & 15 & 15 & 15 & 15 & 75 & 15 & 10 & 11 & 15 & 15 & 15 & 81 & 231 & $\begin{array}{l}\text { AS, FA, FE, LB, NC, PN, RH, SI, } \\
\text { TB, WH }\end{array}$ \\
\hline Maerua juncea Pax subsp. crustata (Wild) Wild & Capparaceae & $\mathrm{LC}$ & FA & 1 & 2 & 3 & - & - & 6 & - & _ & _ & _ & - & 0 & _ & _- & - & _ & - & - & $\mathbf{0}$ & 6 & AS, FA \\
\hline
\end{tabular}




\begin{tabular}{|c|c|c|c|c|c|c|c|c|c|c|c|c|c|c|c|c|c|c|c|c|c|c|c|c|}
\hline Markhamia zanzibarica (Bojer ex DC.) K.Schum & Bignoniaceae & NL & FA & - & - & - & - & - & $\mathbf{0}$ & 4 & - & - & - & - & 4 & - & - & - & - & - & - & $\mathbf{0}$ & 4 & PE \\
\hline Mentha longifolia $\mathrm{L}$. & Lamiaceae & $\mathrm{LC}$ & FA & - & - & - & - & - & $\mathbf{0}$ & - & - & - & - & - & $\mathbf{0}$ & - & 1 & - & 1 & 4 & 4 & 10 & 10 & FE \\
\hline Mimusops obovata Nees ex Sond. & Sapotaceae & LC & FA & 11 & 13 & 15 & 11 & & 63 & 13 & 10 & 6 & 6 & 2 & 37 & 7 & 5 & - & 8 & 7 & 6 & 33 & 133 & AS, ST, TB \\
\hline Momordica balsamina $\mathrm{L}$. & Cucurbitaceae & LC & FA & - & - & - & 5 & - & 5 & - & - & - & - & - & $\mathbf{0}$ & - & - & - & - & - & - & $\mathbf{0}$ & 5 & CH \\
\hline Monsonia angustifolia E.Mey. ex A.Rich. & Geraniaceae & $\mathrm{LC}$ & FA & - & - & 14 & - & - & 14 & - & - & - & - & - & $\mathbf{0}$ & - & - & - & - & - & - & $\mathbf{0}$ & 14 & $\mathrm{CP}, \mathrm{CH}, \mathrm{FE}$ \\
\hline Mundulea sericea (Willd.) A.Chev. subsp. sericea & Fabaceae & LC & FA & - & - & - & . & 1 & 1 & - & - & - & 3 & - & 3 & - & - & - & - & - & - & $\mathbf{0}$ & 4 & TB \\
\hline Myrothamnus flabellifolius Welw. & Myrothamnaceae & DDT & $\mathrm{D}$ & 15 & 15 & 14 & 13 & 15 & 72 & - & - & 6 & - & - & 6 & - & 3 & - & 8 & - & 5 & 16 & 94 & HE, TB \\
\hline Ochna pulchra Hook.f. & Ochnaceae & $\mathrm{LC}$ & FA & - & - & - & - & - & $\mathbf{0}$ & - & - & - & - & - & $\mathbf{0}$ & - & - & - & - & - & 4 & 4 & 4 & TB \\
\hline Olea europaea L. subsp. africana (Mill.) P.S.Green & Oleaceae & $\mathrm{LC}$ & FA & - & - & - & - & - & $\mathbf{0}$ & 2 & 3 & 1 & - & 9 & 15 & - & - & - & - & - & - & $\mathbf{0}$ & 15 & AS, TB \\
\hline Osyris lanceolata Hochst. \& Steud. & Santalaceae & LC & $\mathrm{D}$ & 1 & - & 4 & 7 & 1 & 13 & - & 1 & - & - & 4 & 5 & - & - & - & - & - & - & $\mathbf{0}$ & 18 & AS, FA, LA, PN, TB \\
\hline Ozoroa sphaerocarpa R.Fern. \& A. Fern. & Anacardiaceae & $\mathrm{LC}$ & FA & - & - & - & - & - & $\mathbf{0}$ & 5 & - & - & - & - & 5 & - & - & - & - & - & - & $\mathbf{0}$ & 5 & $\mathrm{HE}$ \\
\hline Pappea capensis Eckl. \& Zeyh. & Sapindaceae & $\mathrm{LC}$ & FA & - & - & - & - & - & $\mathbf{0}$ & 1 & - & - & - & - & 1 & - & - & - & - & - & - & $\mathbf{0}$ & 1 & ST \\
\hline Peltophorum africanum Sond. & Fabaceae & LC & FA & 3 & 1 & 2 & 4 & 5 & 15 & 5 & 2 & - & 7 & - & 14 & 7 & 5 & 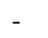 & 1 & 5 & 1 & 19 & 48 & AS, CH, FA, PN, SI, ST, TC \\
\hline Pergularia daemia (Forssk.) Chiov. subsp. daemia & Apocynaceae & $\mathrm{LC}$ & FA & 1 & - & - & - & - & 1 & - & - & - & - & - & 0 & - & - & - & - & - & - & $\mathbf{0}$ & 1 & PN \\
\hline Philenoptera violacea (Klotzsch) Schrire & Fabaceae & $\mathrm{LC}$ & FA & 4 & - & - & 13 & - & 17 & - & - & - & - & - & $\mathbf{0}$ & - & - & - & - & - & - & $\mathbf{0}$ & 17 & $\mathrm{CH}, \mathrm{PN}$ \\
\hline Pleurostylia capensis (Turcz.) Loes & Celastraceae & LC & FA & - & - & - & - & - & $\mathbf{0}$ & 1 & 1 & - & - & - & 2 & - & - & - & - & - & - & $\mathbf{0}$ & 2 & PN, TB \\
\hline \multirow[t]{2}{*}{ Plumbago zeylanica $\mathrm{L}$. } & Plumbaginaceae & NEV & D & 15 & 15 & 15 & 15 & - & 60 & 15 & 15 & - & - & 15 & 45 & 151 & 15 & 15 & 15 & 15 & 15 & 90 & 195 & AS, CH, FE, NC, ST, TB, CP \\
\hline & & & $\mathrm{NE}$ & - & - & - & - & 15 & 15 & - & - & 15 & 15 & - & 30 & - & 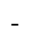 & - & . & - & - & $\mathbf{0}$ & 45 & \\
\hline Portulacaria afra Jag. & Portulacaceae & $\mathrm{LC}$ & FA & 10 & - & - & - & - & 10 & - & - & - & - & - & $\mathbf{0}$ & - & - & - & - & - & - & $\mathbf{0}$ & 10 & TB \\
\hline Pouzolzia mixta Solms var. mixta & Urticaceae & $\mathrm{LC}$ & FA & - & - & - & - & - & $\mathbf{0}$ & - & - & - & - & - & $\mathbf{0}$ & - & 3 & - & 5 & - & 1 & 9 & 9 & TB \\
\hline Pristimera longipetiolata (Oliv.) N.Hall & Celastraceae & $\mathrm{LC}$ & FA & - & - & - & - & - & $\mathbf{0}$ & 2 & - & 1 & - & - & 3 & - & . & - & - & - & - & $\mathbf{0}$ & 3 & TB \\
\hline \multirow[t]{2}{*}{ Protea caffra Meisn. subsp. caffra } & Proteaceae & LC & $\mathrm{D}$ & - & - & - & - & - & $\mathbf{0}$ & - & - & - & - & - & $\mathbf{0}$ & - & - & 11 & - & 15 & - & 26 & 26 & AS, FA, PN, SI, ST, TB \\
\hline & & & FA & 15 & 15 & 15 & 13 & 15 & 73 & 15 & 10 & 11 & 13 & 15 & 64 & 91 & 10 & - & 14 & - & 15 & 48 & 185 & \\
\hline Psiadia punctulata (DC.) Vatke & Asteraceae & LC & FA & 15 & 15 & 15 & 13 & 15 & 73 & 15 & 10 & 11 & 13 & 15 & 64 & 91 & 10 & 11 & 14 & 15 & 15 & 74 & 211 & AS, CH, FE, NC, PN, ST, TB \\
\hline Ptaeroxylon obliquum (Thunb.) Radlk. & Ptaeroxylaceae & $\mathrm{LC}$ & FA & 15 & 3 & 15 & 10 & 15 & 58 & 1 & 15 & 6 & 6 & 6 & 34 & 5 & 1 & - & 4 & 12 & 5 & 27 & 119 & AS, HE, FE, TB \\
\hline Pyrenacantha grandiflora Baill. & Icacinaceae & $\mathrm{LC}$ & FA & - & - & - & - & - & $\mathbf{0}$ & 1 & - & - & - & - & 1 & 9 & - & - & - & - & - & 9 & 10 & AS, TB \\
\hline Rhoicissus tomentosa (Lam.) Wild \& R.B.Drumm. & Vitaceae & LC & FA & - & - & - & - & - & $\mathbf{0}$ & - & - & - & - & 10 & 10 & - & - & - & - & - & - & $\mathbf{0}$ & 10 & AS, PN \\
\hline Rhoicissus tridentata (L.f.) Wild \& R.B.Drumm. subsp. tridentate & Vitaceae & $\mathrm{LC}$ & FA & - & - & - & - & - & $\mathbf{0}$ & - & - & - & - & 3 & 3 & - & - & - & - & - & - & $\mathbf{0}$ & 3 & TB \\
\hline Rhynchosia hirta (Andrews) Meikle \& Verdc. & Fabaceae & $\mathrm{LC}$ & FA & - & - & - & - & - & $\mathbf{0}$ & - & 4 & - & 2 & 15 & 21 & - & - & - & - & - & - & $\mathbf{0}$ & 21 & PE \\
\hline Sansevieria hyacinthoides (L.) Druce & Dracaenaceae & LC & FA & - & - & 3 & - & - & 3 & 6 & 3 & 4 & - & 1 & 14 & - & 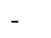 & 2 & - & - & 1 & 3 & 20 & CH, LA \\
\hline Salix macronata Thunb. & Salicaceae & $\mathrm{LC}$ & FA & - & 1 & - & - & - & 1 & - & - & - & - & - & $\mathbf{0}$ & - & - & - & - & - & - & $\mathbf{0}$ & 1 & AG \\
\hline Schotia brachypetala Sond. & Fabaceae & LC & FA & - & - & - & - & - & $\mathbf{0}$ & 5 & 2 & 1 & - & 1 & 9 & - & - & - & - & - & - & $\mathbf{0}$ & 9 & LA, PN, TB \\
\hline Sclerocarya birrea (A.Rich.) Hochst. subsp. caffra (Sol & Anacardiaceae & LC $(\mathrm{P})$ & FA & 14 & 14 & 14 & 14 & 14 & 70 & 8 & 15 & 14 & 14 & 10 & 61 & 11 & 6 & - & 12 & 14 & 11 & 54 & 185 & AS, HE, PN, RH, SI, TB \\
\hline Securidaca longepedunculata Fresen. var. longepedunculata & Polygalaceae & LC (P) & & 15 & 15 & 15 & 15 & 15 & 75 & 15 & 15 & 15 & 15 & 15 & 75 & 151 & 10 & 12 & 15 & 15 & 15 & 82 & 232 & AS, HE, PN, RH, TB \\
\hline Senecio serratuloides DC. & Asteraceae & $\mathrm{LC}$ & FA & - & - & 4 & 3 & - & 7 & 15 & 15 & 15 & 13 & 15 & 73 & - & 4 & - & - & - & - & 4 & 84 & AS, FA, PN, TB, WH \\
\hline \multirow[t]{2}{*}{ Senna italica Mill. subsp. arachoides (Burch.) Lock } & Fabaceae & LC & $\mathrm{D}$ & - & - & - & - & - & $\mathbf{0}$ & - & - & - & - & - & $\mathbf{0}$ & 4 & - & - & - & - & - & $\mathbf{0}$ & 4 & AS, CH, FA, PN, SI, TB \\
\hline & & & FA & - & 1 & - & - & 3 & 4 & - & 3 & 7 & - & - & 10 & 5 & - & - & - & - & - & 5 & 19 & \\
\hline Senna occidentalis (I & Fabaceae & NEV & FA & - & 5 & - & - & - & 5 & - & - & - & - & 1 & 1 & 1 & 1 & 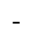 & - & - & - & 2 & 8 & CH, TB \\
\hline Senna petersiana (Bolle) Lock & Fabaceae & $\mathrm{LC}$ & FA & - & - & - & 2 & - & 2 & - & - & - & - & - & $\mathbf{0}$ & - & - & - & - & - & - & $\mathbf{0}$ & 2 & LA, TB \\
\hline Sida cordifolia $\mathrm{L}$. & Malvaceae & $\mathrm{LC}$ & FA & - & - & - & - & 3 & 3 & - & 4 & - & - & - & 4 & - & - & - & - & - & - & $\mathbf{0}$ & 7 & AS, ST \\
\hline \multirow[t]{2}{*}{ Siphonochilus aethiopicus (Schweinf.) B.L.Burtt } & Zingiberaceae & $\mathrm{CR}(\mathrm{P})$ & EX & - & 15 & . & - & - & 15 & . & - & - & - & - & $\mathbf{0}$ & - & - & & 15 & 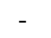 & - & 15 & 30 & AS, CH, RH, SI, TB \\
\hline & & & $\mathrm{NE}$ & - & - & 12 & - & 9 & 21 & 15 & 15 & 12 & 15 & - & 57 & 151 & 15 & 15 & - & 10 & 15 & 70 & 148 & \\
\hline \multirow[t]{2}{*}{ Solanum catombelense Peyr. } & Solanaceae & LC & FA & 15 & 15 & 15 & 15 & 15 & 75 & 15 & 15 & 15 & 15 & 15 & 75 & 151 & 15 & - & 15 & 15 & 15 & 75 & 225 & AS, CH, PN \\
\hline & & & $\mathrm{NE}$ & - & - & - & - & 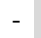 & $\mathbf{0}$ & - & - & - & - & - & $\mathbf{0}$ & - & - & 15 & - & - & - & $\mathbf{0}$ & 15 & \\
\hline Solanum panduriforme E.Mey. & Solanaceae & NL & FA & - & - & - & 5 & - & 5 & - & 3 & 1 & 1 & 6 & 11 & 5 & 1 & - & - & - & 3 & 9 & 25 & AS, HE, LA, SI \\
\hline $\begin{array}{l}\text { Sorghum bicolor (L.) Moench subsp. arundinaceum (Desv.) de } \\
\text { Wet \& Harlan }\end{array}$ & Poaceae & LC & FA & 4 & 15 & - & 3 & 4 & 26 & - & - & . & 15 & - & 15 & - & 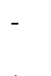 & - & - & - & - & $\mathbf{0}$ & 41 & FA, TB \\
\hline Spirostachys africana Sond. & Euph & LC & FA & 11 & 15 & 7 & 10 & 15 & 58 & 1 & 9 & 6 & 6 & 6 & 28 & 5 & 1 & & 4 & 8 & 5 & 23 & 109 & FA, HE, SI, ST, TB \\
\hline Stachys aethiopica $\mathrm{L}$. & Lamiaceae & LC & FA & - & - & - & - & - & $\mathbf{0}$ & - & - & - & 3 & - & 3 & - & - & - & - & - & - & $\mathbf{0}$ & 3 & TB \\
\hline Strophanthus speciosus (Ward \& Harv.) Reber & Apocynaceae & LC & FA & 15 & 15 & 14 & 13 & 15 & 72 & 15 & 10 & 11 & 13 & 15 & 64 & 151 & 10 & 11 & 14 & 15 & 15 & 80 & 216 & AS, CH, FA, PN, TB \\
\hline Stylochaeton natalensis Schott & Araceae & LC & FA & 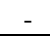 & - & - & & 1 & 1 & 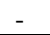 & 2 & 6 & - & 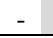 & 8 & - & & - & 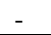 & - & 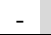 & $\mathbf{0}$ & 9 & AS, PN, RH, SI, ST, TB \\
\hline
\end{tabular}


Syzygium gerrardii (Harv. ex Hook.f.) Burtt Davy Terminalia sericea Burch. ex DC.

Tragia dioica Sond.

Triaspis glaucophylla Engl.

Tulbaghia violacea Harv. var. violacea

urraea obtusifolia Hochs.

Tylosema esculentum (Burch.) A.Schreib.

Tylosema fassoglense (Schweinf.) Torre \& Hillc

Vangueria infausta Burch. subsp. infausta

Vepris reflexa I.Verd.

Vernonia natalensis Sch.Bip. e x Walp.

Vernonia wollastonii S.Moore

Vigna frutescens A.Rich. subsp. frutescens var. frutescens Waltheria indica $\mathrm{L}$.

Warburgia salutaris (G.Bertol.) Chiov.

Withania somnifera (L.) Dunal

Xerophyta retinervis Baker

Ximenia caffra Sond. var. natalensis Sond

Zantedeshia aethiopica (L.) Spreng.

Zanthoxylum capense (Thunb.) Harv.

Zanthoxylum humile (E.A.Bruce) P.G.Waterman

Ziziphus mucronata Willd. subsp. mucronata

Ziziphus zeyheriana Sond.

Myrtaceae
Combretaceae
Euphorbiaceae
Malpighiaceae
Alliaceae
Meliaceae
Fabaceae
Fabaceae
Rubiaceae
Rutaceae
Asteraceae
Asteraceae
Fabaceae
Malvaceae
Canellaceae
Solanaceae
Velloziaceae
Olacaceae
Araceae
Rutaceae

Rutaceae

Rhamnaceae

$\begin{array}{lllllllllll} & \text { D } & 15 & 15 & 15 & 15 & 14 & \mathbf{7 4} & 15 & 13 \\ \text { LC } & \text { FA } & - & - & - & - & - & \mathbf{0} & - & - \\ \text { LC } & \text { FA } & - & 2 & - & - & - & \mathbf{2} & - & 10 \\ \text { LC } & \text { FA } & 6 & - & - & - & - & \mathbf{6} & - & 4 \\ \text { LC } & \text { FA } & 1 & - & - & - & - & \mathbf{1} & - & - \\ \text { LC } & \text { FA } & - & - & - & - & - & \mathbf{0} & - & 3 \\ \text { LC } & \text { FA } & - & - & - & - & - & \mathbf{0} & 1 & - \\ \text { LC } & \text { FA } & - & - & - & - & - & \mathbf{0} & 1 & - \\ \text { LC } & \text { FA } & - & - & 12 & - & - & \mathbf{1 2} & - & - \\ \text { LC } & \text { FA } & - & - & - & - & 1 & \mathbf{1} & - & 2 \\ \text { LC } & \text { FA } & - & - & - & - & - & \mathbf{0} & 1 & 2\end{array}$

NL D

FA

LC FA

LC FA

EN(P)D

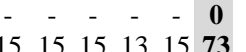

$\begin{array}{llllllllll}- & 15 & \mathbf{7 3} & 15 & 11 & 12 & - & - & \mathbf{0} & - \\ \mathbf{6} & & \mathbf{6 8} & 9\end{array}$

$\begin{array}{ccc}9 & 15 & 15 \\ - & - & - \\ - & - & - \\ - & 1 & - \\ - & - & - \\ 5 & - & - \\ 1 & 1 & 1 \\ - & - & - \\ - & - & - \\ 2 & - & 6 \\ - & - & -\end{array}$

\begin{tabular}{c|c|}
\hline 67 \\
0 \\
10 \\
5 \\
0 \\
8 \\
4 \\
1 \\
0 \\
10 \\
3 \\
\hline
\end{tabular}

$\begin{array}{llllllll}15 & 15 & 15 & 15 & 15 & 15 & \mathbf{9 0} & \mathbf{2 3 1}\end{array}$

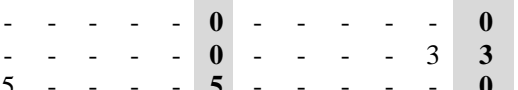

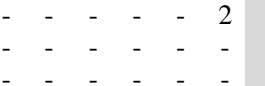

$12 \mathrm{FA}, \mathrm{TB}$

11 FA, ST, TB

0 1 LA

8 NC, $\mathrm{TB}$

4 CH

0 1 1 HE

$\begin{array}{llll}0 & 12 & \text { TB } \\ 1 & 12 & \text { HE, }\end{array}$

0 3 FA, HE

2626 AS, CH, HE, FE, SI, TB

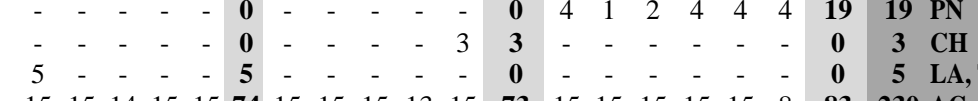

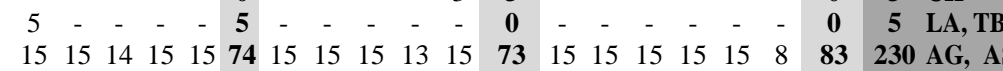

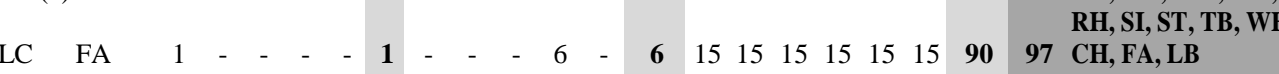

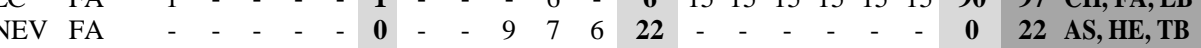

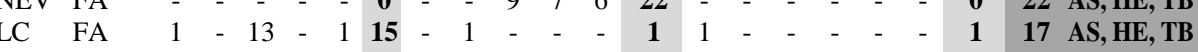

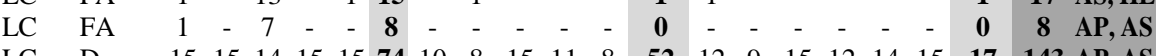

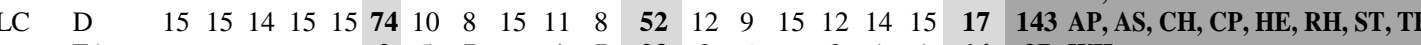

$\begin{array}{lllllllllllllllllllllll}\text { FA } & - & - & - & - & - & \mathbf{0} & 5 & 7 & - & 4 & 7 & \mathbf{2 3} & 3 & 6 & - & 3 & 1 & 1 & \mathbf{1 4} & \mathbf{3 7} & \mathbf{W H}\end{array}$

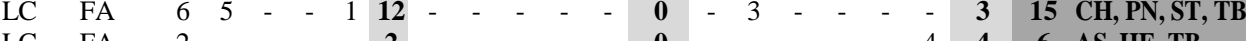

$\begin{array}{llllllllllllllllllllllll}\text { LC } & \text { FA } & 2 & - & - & - & - & \mathbf{2} & - & - & - & - & - & \mathbf{0} & - & - & - & - & - & 4 & \mathbf{4} & \mathbf{6} & \text { AS, HE, TB } \\ \text { LC } & \text { FA } & 15 & 15 & 14 & 13 & 15 & \mathbf{7 2} & 15 & 10 & 11 & 13 & 15 & \mathbf{6 4} & 9 & 9 & 11 & 13 & 12 & 12 & \mathbf{6 6} & \mathbf{2 0 2} & \text { TB } & \end{array}$

Note: Conservation criteria as outlined in the South African National Red Data List of plants (Critically endangered (CR): a species is CR when the best available evidence indicates that it meets at least one of the five IUCN (International Union for Conservation of Nature) criteria for CR, indicating that the species is facing an extremely high risk of extinction, Data Deficient - Insufficient Information (DDT): a species is DDT when taxonomic problems hinder the distribution range and habitat from being well defined, so that an assessment of risk of extinction is not possible, Endangered (EN): a species is EN when the best available evidence indicates that it meets at least one of the five IUCN criteria for EN, indicating that the species is facing a very high risk of extinction, Extinct in the wild (EX): a species is EX in the wild when it is known to survive only in cultivation or as a naturalized population well outside the past range, List concern (LC): a species is LC when it has been evaluated against the IUCN criteria and does not qualify for any of the above categories. Species classified as Least Concern are considered at low risk of extinction, Not evaluated (NEV): a species is NE when it has not been evaluated against the IUCN criteria, Vulnerable (VU): a species is VU when the best available evidence indicates that it meets at least one of the five IUCN criteria for VU, indicating that the species is facing a high risk of extinction, Near Threatened (NT): a species is NT when available evidence indicates that it nearly meets any of the IUCN criteria for VU, and is therefore likely to become at risk of EX in the near future, Declining (D): a species is D when it does not meet or nearly meet any of the five IUCN criteria and does not qualify for CR, EN, VU or NT, but there are threatening processes causing a continuing D of the species), Not listed (NL): species not listed on the South African National Red Data List of plants, Protected (P): species legally protected by a particular piece of legislation, Not identified (NI): species not identified by researcher due to lack of diagnostic features, fairly abundant (FA): species considered by THs as still fairly abundant in the wild, ailments treated (angina pain; AG, asthma: AS, aphonia: AP, chronic cough: $\mathbf{C H}$, chest pain: $\mathbf{C P}$, fatigue: FA, fever: FE, headache: HE, lack of appetite: $\mathbf{L A}$, laboured breathing: LB, Nasal congestion: NC, painful eyes: PE, pneumonia: PN, rhinitis: RH, sinusitis: SI, sore throat: ST, tuberculosis: TB, tight chest: TC and wheezing: WH). 